\title{
GEOLOGY AND GEOCHEMISTRY CONSTRAINTS ON THE GENESIS OF THE NO.2 PORPHYRY COPPER-GOLD DEPOSIT IN THE XIONGCUN DISTRICT, GANGDESE PORPHYRY COPPER BELT, TIBET, CHINA
}

\author{
YIN, Q. ${ }^{1}$ - LANG, X. ${ }^{1,2^{*}}-$ CUI, Z. ${ }^{1}-$ YAN, Z. ${ }^{1}-$ XIE, F. ${ }^{1}-$ WANG, X. ${ }^{1}$ \\ ${ }^{l}$ College of Earth Science and MLR Key Laboratory of Tectonic Controls on Mineralization and \\ Hydrocarbon Accumulation, Chengdu University of Technology, Chengdu 610059, China \\ ${ }^{2}$ State Key Laboratory of Ore Deposit Geochemistry, Institute of Geochemistry, Chinese \\ Academy of Sciences, Guiyang 550002, China \\ Corresponding author \\ e-mail: langxinghai@126.com
}

(Received 22 $2^{\text {nd }}$ Jul 2016; accepted $9^{\text {th }}$ Nov 2016)

\begin{abstract}
The Xiongcun district is located in the western segment of the Gangdese porphyry copper belt (GPCB). The No.2 deposit in the Xiongcun district hosts a measured and indicated resource of $1.34 \mathrm{Mt}$ copper, $76.34 \mathrm{t}$ gold, and $193.78 \mathrm{t}$ silver. The copper-gold mineralization of the No.2 deposit is mainly hosted in the Early Jurassic quartz diorite porphyry which intruded volcano-sedimentary rocks of the Early Jurassic Xiongcun Formation. $\mathrm{S}$ and $\mathrm{Pb}$ isotopic compositions of the ore sulfides and Re contents of molybdenite suggest a mantle source with minor contamination of subducted sediments for the ore-forming materials. Hydrogen and oxygen isotopic compositions of quartz from the quartz - sulfide veins suggest that the ore-forming fluid was a mixture of magmatic and meteoric water. Geochemical and $\mathrm{Sr}-\mathrm{Nd}-\mathrm{Hf}$ isotopic compositions of the Early Jurassic quartz diorite porphyry suggest that the mineralization of the No.2 deposit formed in an intra-oceanic island arc setting. The magmas of the Early Jurassic quartz diorite porphyry were likely sourced from partial melting of mantle with limited contamination by subducted sediments (ca. 5\%). The formation of the porphyry and the No.2 deposit were related to the northward intra-oceanic subduction of the Neo-Tethys oceanic slab during the Early Jurassic.
\end{abstract}

Keywords: porphyry deposit, Gangdese, Lhasa terrane, Xiongcun, island arc

\section{Introduction}

The Gangdese porphyry copper belt (GPCB), located in the southern margin of the Lhasa terrane (Fig. $1 a-b)$, is an important metallogenic belt in the Tibetan Plateau (Qu et al., 2001; Hou et al., 2003). In the past 15 years, many porphyry $\mathrm{Cu}(\mathrm{Mo}, \mathrm{Au})$ deposits and skarn $\mathrm{Pb}-\mathrm{Zn}$ polymetallic deposits have been discovered in the GPCB (Fig. 1c), including Xiongcun, Jiama, Qulong, Tinggong, Chongjiang, Jiru, etc. (Hou et al., 2003, 2011; Meng et al., 2003; Rui et al., 2003; Li et al., 2005; Zheng et al., 2007, 2014; Tang, 2009a, 2009b; Xu et al., 2009; Tafti et al., 2009, 2014; Yang et al., 2009; Lang et al., 2014a; Zhao et al., 2014; Wang et al., 2015). The metallogenesis of the GPCB is related to norhward subduction of the Neo-Tethys Oceanic slab and subsequent Indian-Eurasian continental collision (Mao et al., 2014; Lang et al., 2014a; Tang et al., 2015; Hou et al., 2015). Most porphyry deposits in the GPCB are associated with collision of India with the Eurasian plate (Hou et al., 2003; Meng et al., 2003; Rui et al., 2003; Li et al., 2005; Zheng et al., 2007, 2014), whereas Neo-Tethys subduction-related metallogenesis was only recently discovered in the Xiongcun district (Tafti et al., 2009, 
2014; Mao et al., 2014; Lang et al., 2014a; Tang et al., 2015; Hou et al., 2015).

Two large porphyry copper-gold deposits (i.e. No.1 and No.2) have been explored in the Xiongcun district (Fig. 1d). A total of 47,279 m of core was drilled in 201 diamond drill holes at the No.1 depsoit. Detail evaluation in 2012 showed that the No.1 deposit contains a resource of $1.04 \mathrm{Mt}$ copper, $143.31 \mathrm{t}$ gold and $900.43 \mathrm{t}$ silver with an average grade of $0.48 \%$ copper, $0.66 \mathrm{~g} / \mathrm{t}$ gold, and $4.19 \mathrm{~g} / \mathrm{t}$ silver (Tang et al., 2012). The newly discovered No.2 deposit is located at $3.4 \mathrm{~km}$ northwest of the No.1 deposit (Fig. 1d). 34 diamond drill holes totaling 15,936 m were completed at the No.2 deposit. A detailed evaluation in 2012 showed that the No.2 deposit hosts a resource of 1.34 Mt copper, $76.34 \mathrm{t}$ gold, and $193.78 \mathrm{t}$ silver; the average grade is $0.35 \%$ copper, $0.22 \mathrm{~g} / \mathrm{t}$ gold and $1.30 \mathrm{~g} / \mathrm{t}$ silver (Tang et al., 2012). At present the No.1 deposit is moving forward to the mine construction stage, whereas the No. 2 deposit is still being explored (Tang et al., 2012). Other important mineralization in the Xiongcun district is the No.3 deposit, which is under exploration at the present time (Fig. 1d; Lang et al., 2014b). The latest exploration results (Tang et al., 2012) and geochronology research (Lang et al., 2014a) show that mineralization in the No.2 deposit is related to the 181-175 Ma (zircon U-Pb age) Early Jurassic quartz diorite porphyry and formed ca. 172.6 $\pm 2.1 \mathrm{Ma}$ (molybdenite Re-Os age), whereas mineralization at the No.1 deposit is related to the 167-161 Ma (zircon U-Pb age) Middle Jurassic quartz diorite porphyry and formed ca.161.5 \pm 2.7 Ma (molybdenite Re-Os age). According to previous studies in the Xiongcun district (Tang et al., 2007, 2012,2015; Xu et al., 2006; Tafti et al., 2009, 2014; Lang et al., 2014a), the No.1 deposit contains abundant hypogene pyrrhotite and andalusite, has $\mathrm{CH}_{4}$-rich fluid inclusions and only minor magnetite, and an absence of primary anhydrite, while the No.2 deposit is analogous to classic porphyry copper-gold deposits with abundant primary magnetite and anhydrite, and $\mathrm{CO}_{2}$-rich fluid inclusions (Burnham et al., 1979, 1980; Seedorff et al., 2005). Xu et al. (2009), Tafti et al. (2009, 2014) and Tang et al. (2015) describe geology and genesis of No.1 deposit. However, the newly discovered No.2 deposit is only reported geology and geochronology by Tafti et al. (2009, 2014) and Lang et al. (2014a), for its geochemistry and genesis is poor known. Based on the latest geological exploration results (Tang et al., 2012), herein we report the alteration, mineralization and geochemistry of the No.2 deposit. These data not only provide the new information of the geological characteristics and place constraints on the genesis of the No.2 deposit, but also is important for better understanding the subduction-related metallogenesis in the GPCB.

\section{Geological setting}

The Lhasa terrane is bounded to the north by the Banggong-Nujiang suture (BNS) and to the south by the Indus-Yarlung suture (IYS) (Fig. 1b; Yin and Harrison, 2000). The Xiongcun district is located in the western segment of the GPCB (Fig. 1b-c) in the southern part of the Lhasa terrane. The southern margin of the Lhasa terrane records the tectonic evolution from the subduction of the Neo-Tethys oceanic slab, which began in the Late Triassic - Jurassic or earlier (Mo et al., 2005; Chu et al., 2006, 2011; Zhang et al., 2007; Ji et al., 2009; Tang et al., 2010; Guo et al., 2013; Lang et al., 2014a), to the Indian-Asian continental collision, which began in the Paleocene (ca. 65-50 Ma) (Yin and Harrison, 2000; Mo et al., 2003; Ding et al., 2005). To the south of the Lhasa terrane, the

Late Cretaceous to Early Tertiary Xigaze fore-arc basin is locally well-preserved within the Indus-Yarlung suture zone (Fig. 1c; Yin et al., 1994; Durr, 1996). 

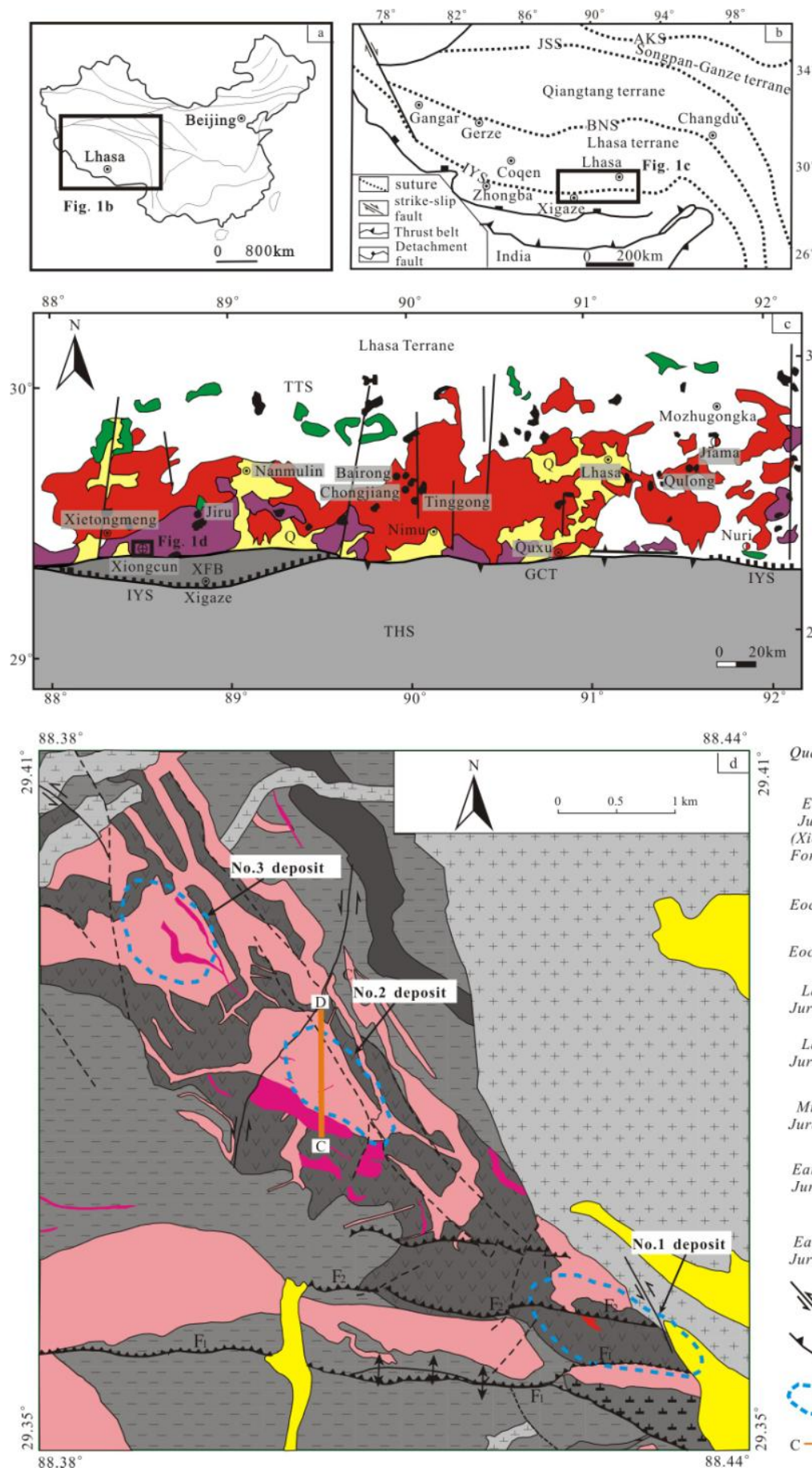

IYS Indus-Yarlung suture

BNS Bangong-Nujiang suture

JSS Jinshajiang suture

" AKS Ayimaquin-Kunlun suture

Gangdese porphyry copper belt

Arc granitoids

Collisional granitoids

Oligocene granites

Miocene porphyry intrusion

Normal fault Thrust fault

Porphyry Porphyry-skarn

Cu-Modeposit $\square$ Cu-Mo(Pb-Zn

Porphyry

Triassic-Tertiary volcanic-sedimentary sequence

THS Tethyan Himalayan sequence

XFB Xigaze forearc basin

GCT Gangdese central thrust

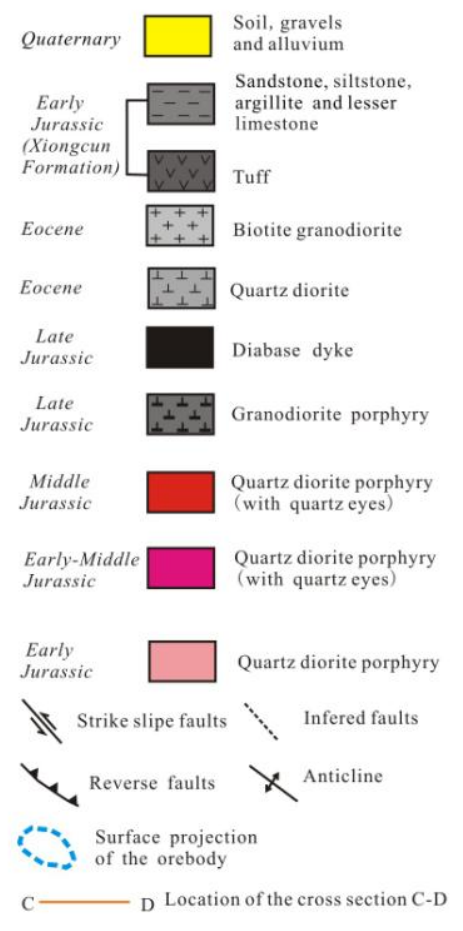

Figure 1. (a). Simplified map of China showing the location of the Himalayan-Tibetan orogen. (b). Simplified regional geological map of the Himalayan-Tibetan orogen showing the location of Gangdese porphyry copper belt (GPCB), modified from Hou et al., 2004 and Yang et al., 2009. (c). Simplified geological map of GPCB showing the ore deposits formed during the Neo-tethys oceanic subduction and Indian-Asia continental collision, modified from Hou et al., 2004 and Li et al., 2011. (d). Geological map of the Xiongcun district, modified from Oliver, (2006)

The southern margin of the Lhasa terrane is dominated by the voluminous Gangdese batholith and the Triassic - Tertiary volcanic-sedimentary sequence (Mo et al., 2005; 
Pan et al., 2006; Zhu et al., 2009, 2011; Ji et al., 2009). Four major stages of magmatic activity have been identified in the Gangdese Batholith, i.e, Triassic - Jurassic, Cretaceous, Paleocene - Eocene and Miocene (Ji et al., 2009). The Triassic - Jurassic and Cretaceous intrusions are associated with northward subduction of the Neo-Tethys oceanic plate (Yin and Harrison, 2000; Mo et al., 2005; Li et al., 2011; Lang et al., 2014a), whereas Paleocene - Eocene and Miocene intrusions are related to the Indo-Asian continental collision. The Triassic - Tertiary volcanic-sedimentary sequence are predominantly the Paleocene - Eocene Linzizong volcanic succession, which consists of the andesitic lower Dianzhong Formation, dacitic middle Nianbo Formation, and the rhyolitic upper Pana Formation, and was formed during initial collision of Indo-Asian continent at ca. 69 Ma-43 Ma (Mo et al., 2003; He et al., 2007; Lee et al., 2009). The sedimentary cover is limited, and the Early Jurassic to Cretaceous volcanic rocks (e.g., Yeba Formation and Sangri Group) are only sporadically distributed in the southern margin of the Lhasa terrane (Pan et al., 2006; Zhu et al., 2008, 2009).

Many porphyry and skarn deposits have been discovered in the southern margin of the Lhasa terrane (Fig. 1c). Jurassic quartz diorite porphyries are related to the porphyry copper-gold deposits, such as No.1, No.2 and No.3 deposits in the Xiongcun district (Tang et al., 2007; Tafti et al., 2009, 2014; Lang et al., 2014a). The Paleocene - Eocene monzogranite or granite porphyry is associated with several porphyry copper (molybdenum) deposits, e.g. Jiru (Zhang et al., 2008). The Miocene granodiorite or monzogranite porphyry is related to many porphyry $\mathrm{Cu}(\mathrm{Mo}, \mathrm{Au})$ deposits and skarn $\mathrm{Pb}-\mathrm{Zn}$ polymetallic deposits, including Qulong, Chongjiang, Tinggong, Jiama et al. (Qu et al., 2001; Hou et al., 2004; Li et al., 2011).

\section{Ore deposit geology}

\section{Strata}

The strata exposed in the Xiongcun district belonging to the Early Jurassic Xiongcun Formation (Fig. 1c), which comprises tuff, sandstone, siltstone, argillite, and lesser limestone (Tang et al., 2007). The disseminated and vein style mineralization occurs mainly in the tuff which has zircon U-Pb ages of $195.0 \pm 4.6 \mathrm{Ma}$ and $176 \pm 5 \mathrm{Ma}(\mathrm{Qu}$ et al., 2007; Tang et al., 2010). The NW-striking, NE-dipping tuff outcropping in the central part of the Xiongcun district, is the dominant host wall-rock into which the ore-related porphyries were emplaced.

\section{Ore-related porphyry}

Mineralization in the No.2 deposit is genetically associated with the Early Jurassic quartz diorite porphyry (Figs. 1d, 2 and 3a). This Early Jurassic quartz diorite porphyry has a porphyritic texture with the phenocrysts of plagioclase (35-45 vol.\%), hornblende (15 vol.\%), and quartz (<10 vol.\%; <1-cm-long) (Fig. 3a). Microcrystalline plagioclase, hornblende, quartz and biotite define the groundmass, which occupies 30-50\% vol percent of the porphyry. A barren Early-Middle Jurassic quartz diorite porphyry, with a zircon U-Pb age of $174.4 \pm 1.6 \mathrm{Ma}$ (Lang et al., 2014c), intruded the Early Jurassic quartz diorite porphyry in the No.2 deposit (Figs. 1d and 2). 


\section{Orebody}

The No.2 deposit is a NW-trending, tabular body, with the dimensions of about 900 $\mathrm{m}$ by $500 \mathrm{~m}$ (Figs. $1 d$ and 2). Veinlets and disseminated pyrite-chalcopyrite mineralization are mainly hosted within the Early Jurassic quartz diorite porphyry and the surrounding tuff. The orebody dips approximately $26^{\circ}-70^{\circ}$ to the northeast (Figs. $1 d$ and 2). It is still open down-dip to the north (Fig. 3) and along strike to the northwest and southeast (Figs. $1 d$ and 2). Supergene enrichment is weakly developed in the No.2 deposits; most of the resources are hosted in the hypogene zone.

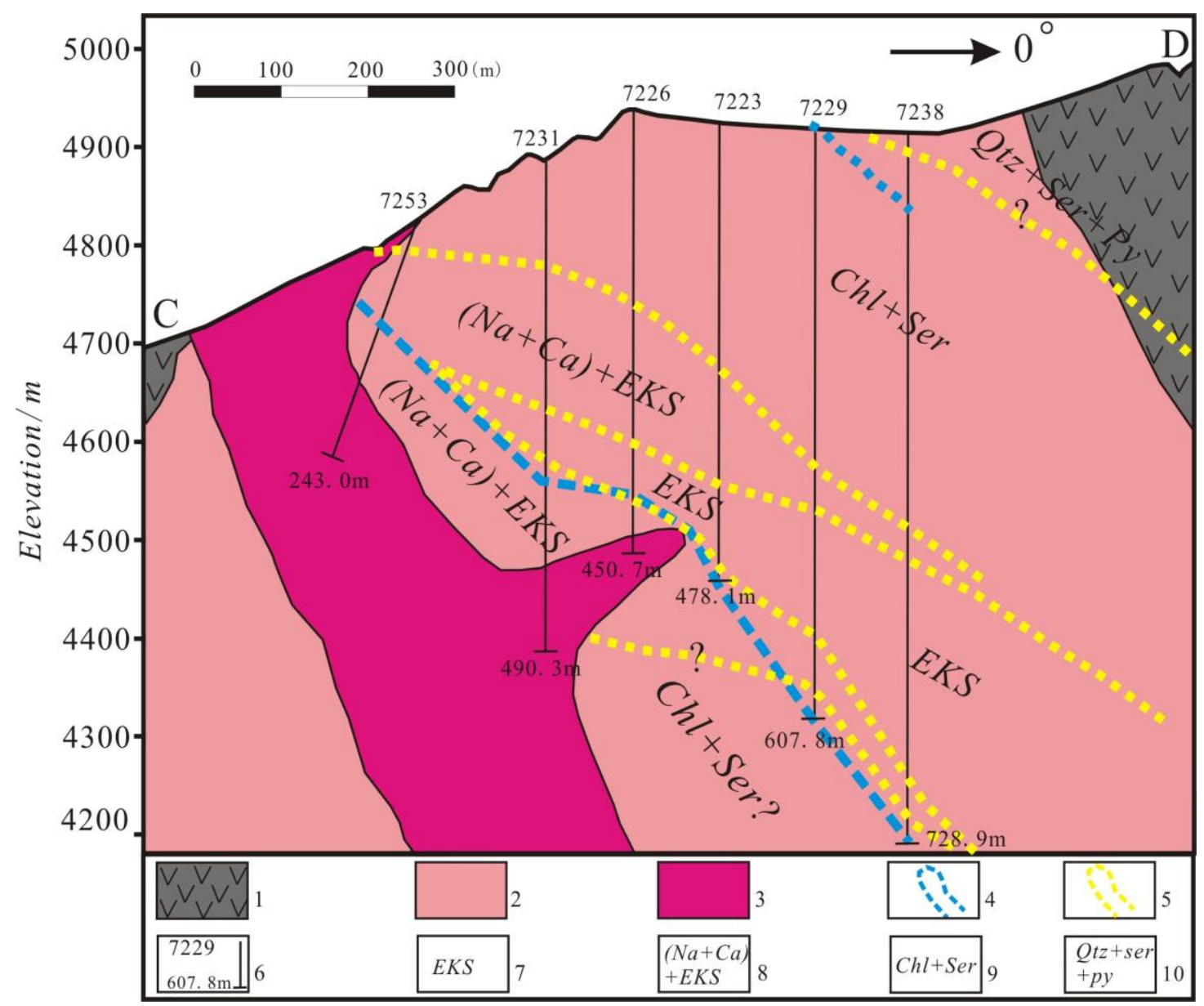

Figure 2. Cross secting of C-D (see Fig. 1) of the No.2 deposit in the Xiongcun district. $1=$ Tuff; $2=$ Early Jurassic quartz diorite porphyry; 3 = Early-Middle Jurassic quartz diorite porphyry; 4 $=$ Boundary of the orebody (cutoff grade of $0.15 \%$ copper); $5=$ Boundary of alteration zones; $6=$ Drill hole and depth; $7=$ Potassic alteration; $8=$ Sodic-calcic alteration overprinting potassic alteration; $9=$ Chlorite-sericite alteration; $10=$ Phyllic alteration. Drill holes of 7223, 7229 and 7238 have not defined the footwall of the orebody, and the orebody is also opens down-dip to the north

\section{Alteration}

In the No.2 deposit, the mineralized porphyry and the tuffs proximal to porphyry show obvious alteration similar to that in other porphyry copper-gold deposits (Sillitoe, 2010), including potassic alteration, sodic-calcic alteration, chlorite-sericite alteration, 
phyllic alteration and propylitic alteration (Fig. 2).

The potassic alteration (Figs. 2 and $3 b$ ) is dominated by biotite and quartz, with variable concentrations of magnetite and locally minor K-feldspar. This assemblage is widely developed in the deposit but commonly overprinted by sodic-calcic alteration and chlorite-sericite alteration, so it only well-preserved in the central and deeper parts of the deposit. The highest grade copper-gold mineralization is mainly associated with potassic alteration.
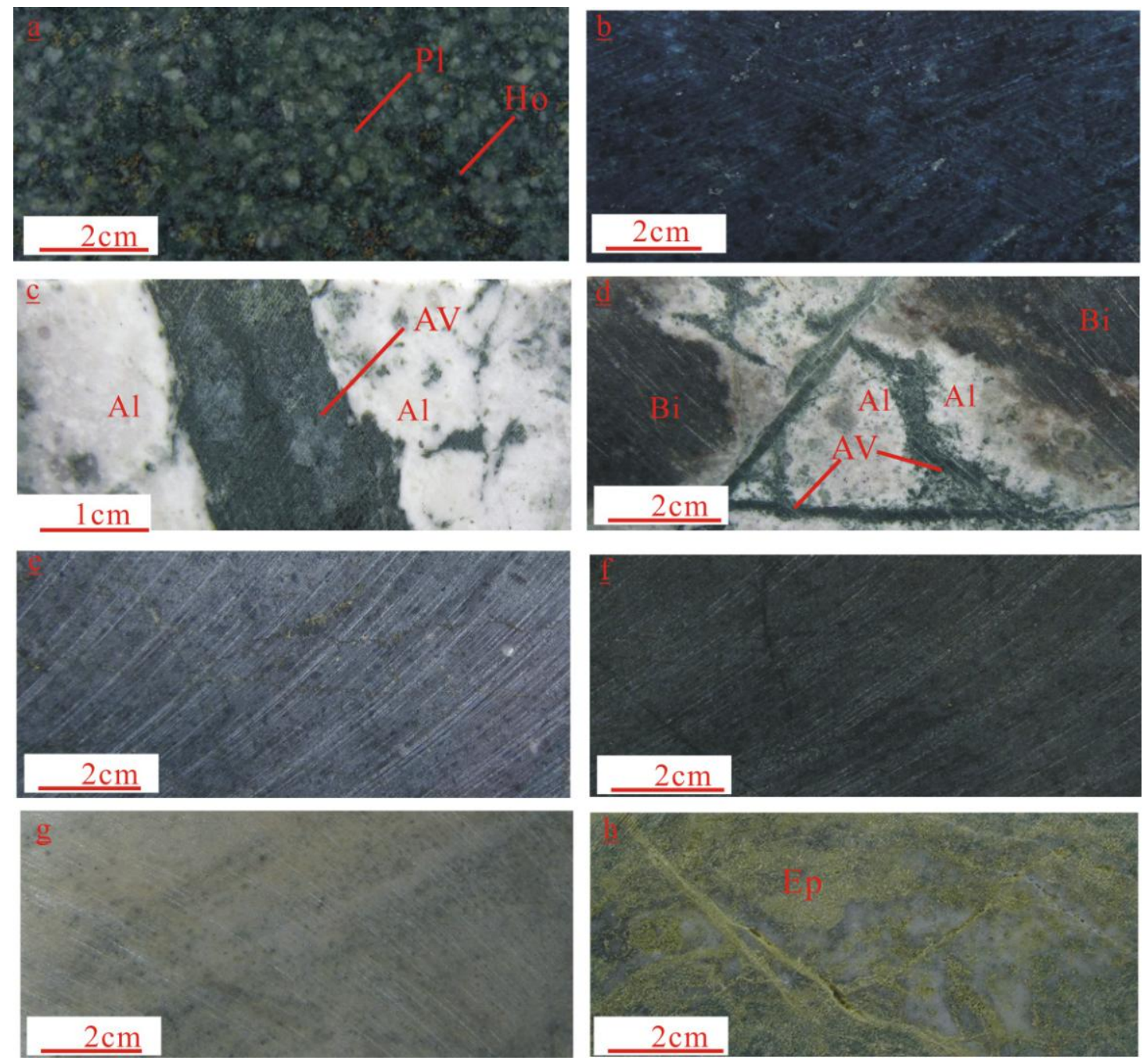

Figure 3. Early Jurassic quartz diorite porphyry and hydrothermal alteration types of the No.2 deposit in the Xiongcun district. (a) Early Jurassic quartz diorite porphyry with phenocrysts of plagioclase and minor hornblende and quartz; (b) Potassic alteration comprising biotite and magnetite; (c) Sodic-calcic alteration, white albite occurs in the selvages of an actinolite vein (AV); (d) Sodic-calcic alteration overprinting potassic alteration; (e) Chlorite-sericite alteration, minor clay can be observed in the rock; (f) Chlorite-sericite alteration overprinting potassic alteration; $(g)$ Phyllic alteration with fine-grained pyrite; ( $h$ ) Propylitic alteration. Abbreviations: $A V=$ Actinolite vein, $P l=$ Plagioclase, $H o=$ Hornblende, $A l=$ Albite, $B i=$ Biotite, Ep = Epidote 
Sodic-calcic alteration (Figs. 2, 3c and $3 d$ ) is comprised of various concentrations of albite, actinolite, magnetite, epidote, chlorite and quartz, with low to no sulfides. Where barren sodic-calcic alteration overprints the mineralized potassic alteration it contains high concentrations of chalcopyrite.

Chlorite-sericite alteration (Figs. 2, $3 e$ and $3 f$ ) is dominated by chlorite, sericite quartz and minor clay and epidote. This alteration is widespread in the shallower parts of the deposit, where it overprints preexisting potassic alteration. Due to the high chalcopyrite content of the preexisting potassic alteration, the weakly mineralized chlorite-sericite alteration also contains high concentrations of copper and gold.

Phyllic alteration (Figs. 2 and $3 g$ ) is composed mainly of quartz, sericite, pyrite and minor chlorite and epidote. This alteration commonly contains a higher ratio of pyrite to chalcopyrite than other alteration zones. The low-grade to nearly barren phyllic alteration is distributed in the upper parts of the deposit.

Propylitic alteration (Fig. 3h) is dominated by chlorite, epidote, carbonate, quartz and minor sericite and pyrite. The barren propylitic alteration is found only locally in the No.2 deposit, but is extensively developed in the northwest part of the Xiongcun district.

\section{Veins}

Hydrothermal veins are extensively developed in the No.2 deposit. The major types of the veins, from oldest to youngest, including quartz - sulfide veins, magnetite sulfide veins, quartz - molybdenite - sulfide veins, biotite - sulfide veins, chlorite sulfide veins, actinolite veins, chalcopyrite - pyrite veins, pyrite veins, anhydrite veins, and other post-ore, barren vein types. The main mineralized vein types in the No.2 deposit are the quartz - sulfide veins, biotite - sulfide veins, magnetite - sulfide veins and chlorite - sulfide veins.

Quartz - sulfide veins (QSV; Fig. 4a-d, $g$ and $i$-l) are found mainly in the potassic alteration zone and chlorite-sericite alteration zone. The major minerals are quartz, pyrite and chalcopyrite. Quartz - sulfide veins are the earliest vein types and are commonly associated with high grade copper-gold mineralization.

Quartz - molybdenite - sulfide veins (QMS; Fig. 4a) are observed mainly in the potassic alteration zone, with a relatively higher concentration in the deeper parts of the deposits. This vein type is rare in the No.2 deposit. They consist mainly of quartz, molybdenite and minor pyrite and chalcopyrite. QMS are younger than quartz - sulfide veins (Fig. 4a). Magnetite - sulfide veins (MSV; Fig. 4b) mainly contain magnetite, pyrite, chalcopyrite and minor biotite and quartz. MSV commonly occur in the potassic alteration zone and chlorite-sericite alteration zone with high grade copper-gold mineralization. In many instances, MSV cut Quartz - sulfide veins (Fig. 4b). Biotite sulfide veins (BSV; Fig. 4c) are found mainly in the potassic alteration zone and are minor in the chorite-sericite alteration zone. BSV mainly comprise biotite, pyrite, chalcopyrite and minor magnetite and quartz. BSV contain high grade copper-gold mineralization. BSV are younger than quartz - sulfide veins (Fig. 4c). Chlorite - sulfide veins (CSV; Fig. 4e-f and $h$ ) occur mainly in the chlorite-sericite alteration zone. CSV mainly comprise chlorite, quartz, epodite, pyrite, chalcopyrite and minor biotite and actinolite. In many places, where potassic alteration alteration is overprinted by variable amounts of chlorite-sericite alteration, the CSV are abundant. These veins have transitional characteristics with biotite - sulfide veins, such as similar shapes and some remnant of biotite still present within the CSV. So, chlorite - sulfide veins are probably partially to completely chloritized biotite - sulfide veins. 

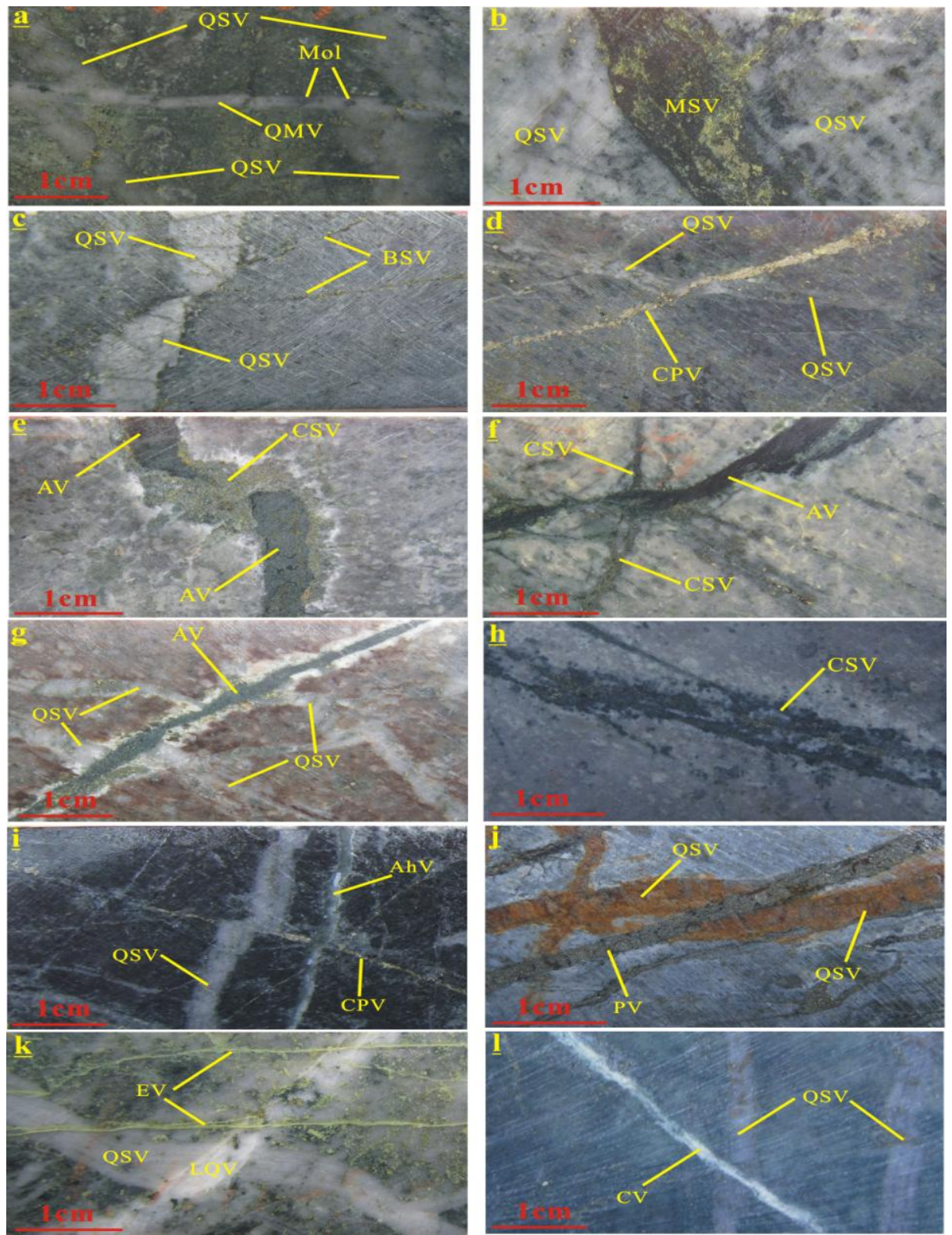

Figure 4. Hydrothermal vein types of the No.2 deposit in the Xiongcun district. Photos also show the relationships of the vein types: (a) Quartz - molybdenite - sulfide - vein cutting a quartzsulfide vein; (b) Magnetite - sulfide vein cutting a quartz - sulfide vein; (c) Biotite - sulfide vein cutting a quartz - sulfide vein; (d) Chalcopyrite - pyrite vein cutting a quartz - sulfide vein; $(e)$ and (f) Actinolite vein cutting a chlorite - sulfide vein, white albite occurs in the selvages of the actinolite vein; $(g)$ Actinolite vein cutting a quartz - sulfide vein, white albite occurs in the selvages of the actinolite vein; ( $h$ ) Showing green chlorite - sulfide veins; (i) Chalcopyrite pyrite vein cutting a quartz - sulfide vein, with the chalcopyrite - pyrite vein cut by anhydrite vein; $(j)$ pyrite vein cutting a quartz - sulfide veins; $(k)$ Late quartz vein cutting a quartz - sulfide vein, with the late quartz vein cut by epidote vein; (l) Carbonate vein cutting a quartz - sulfide vein. Abbreviations: $Q S V=$ Quartz - sulfide vein, $M S V=$ Magnetite - sulfide vein, $B S V=$ Biotite - sulfide vein, $Q M V=$ Quartz - molybdenite - sulfide - vein, $C P V=$ Chalcopyrite - pyrite vein, $A V=$ Actinolite vein, $C S V=$ Chlorite - sulfide vein, $P V=$ Pyrite vein, $A h V=$ Anhydrite vein, $E V$

$=$ Epidote vein, $C V=$ Carbonate vein, $L Q V=$ Late quartz vein 
Actinolite veins (AV; Fig. 4e-g) are the main veins within the sodic-calcic alteration zone but are also present in the chlorite-sericite and potassic alteration zone. They commonly have white albite selvages. The main minerals are actinolite, magnetite and minor quartz, chlorite, epidote, tourmaline and pyrite. Where actinolite veins overprint older veins, such as QSV and CSV, the older veins also formed white albite selvages (Fig. $4 e$ and $g$ ). Actinolite veins are normally barren but locally ore bearing where they overprint ore-bearing vein types. Actinolite veins cut the quartz - sulfide and chlorite sulfide veins (Fig. 4e-g).

Chalcopyrite - pyrite veins (CPV; Fig. $4 d$ and $i$ ) are strongly mineralized copper-gold but are rare in the No.2 deposit. They are distributed mainly in the potassic alteration zone, and are dominated by pyrite, chalcopyrite and minor quartz. Chalcopyrite - pyrite veins are younger than quartz - sulfide veins (Fig. $4 d$ and $i$ ).

Pyrite veins (PV; Fig. $4 g$ ) occur mainly in the phyllic alteration zone. These veins are dominated by pyrite with minor quartz and sericite, and locally contain traces of chalcopyrite. Poor copper-gold mineralization occurs in the pyrite veins. PV is younger than the above vein types.

Anhydrite veins (AhV; Fig. 4i) distributed mainly in the deeper parts of the potassic alteration zone. The barren anhydrite veins comprise anhydrite, quartz and minor epidote with no sulfides. The exact timing of anhydrite veins is not obvious but in many instances they cut all of the other mineralization-stage vein types (Fig. 4i).

Other post-ore, barren vein types: These vein types include late quartz veins (LQV; Fig. 4k), carbonate veins (CV; Fig. 4l) and epidote veins (EV; Fig. 4k). They occur throughout the deposit. LQV are dominated by white, cryptocrystalline quartz with very minor sulfides locally. CV are dominated by calcite and minor quartz with no sulfides. EV are dominated by epidote with minor calcite, sericite and quartz with no sulfides. These veins commonly cut QSV, BSV and PV.

\section{Mineralization stage}

There are various mineralization types including veins, disseminations, veinlet-dissemination and stockwork veining in the No.2 deposit. The dominant metallic minerals are pyrite, chalcopyrite and magnetite. The nonmetallic minerals include quartz, chlorite, biotite, sericite, plagioclase, hornblende, albite, actinolite, epidote and anhydrite. According to the mineral assemblages, microscopic study and crosscutting relationships of various veins (Fig. 4), four main stages of hypogene alteration - mineralization and one epigenetic stage have been identified at the No.2 deposit (Fig. 5).

Stage I: Veinlet-disseminated high grade copper-copper mineralization occurred in this stage. Metallic minerals are mainly pyrite, chalcopyrite and magnetite, rarely molybdenite and pyrrhotite, with nonmetallic minerals comprising quartz, biotite, K-feldspar, muscovite, sericite, chlorite, epidote and anhydrite.

Stage II: Barren to low grade copper - copper mineralization occurred in this stage. The mineral assemblage contains minor pyrite, magnetite and chalcopyrite, with the nonmetallic minerals comprising quartz, albite, actinolite, epidote, sericite and chlorite.

Stage III: Low grade copper - gold mineralization occurred in this stage. The mineral assemblage contains minor pyrite and chalcopyrite, with the nonmetallic minerals comprising quartz, chlorite, sericite, and minor clay, epidote and carbonate.

Stage IV: Low grade copper - copper mineralization occurred in this stage. The mineral assemblage contains pyrite, minor chalcopyrite and rarely sphalerite and galena, 
with the nonmetallic minerals comprising quartz, sericite, chlorite, epidote, clay and carbonate.

Stage V: the epigenetic stage, which is marked by supergene oxidation, resulting in the formation of some secondary minerals (e.g., malachite, chalcocite, hematite and limonite). The oxide zone and supergene zone of the deposit were formed in this stage. Epigenetic enrichment is weak in the No.2 deposits and most of the copper-gold resource is hosted in the hypogene zone.

\begin{tabular}{|c|c|c|c|c|c|}
\hline Minerals Stages & Stage I & Stage II & Stage III & Stage IV & Epigenetic stage \\
\hline Quartz & 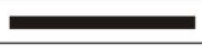 & (................ & - & & \\
\hline \multicolumn{6}{|l|}{ Biotite } \\
\hline $\mathrm{K}$-feldspar & n............... & & & & \\
\hline Muscovite & [............... & & & & \\
\hline \multicolumn{6}{|l|}{ Anhydrite } \\
\hline Sericite & ................ & n................ & - & - & \\
\hline Epidote & $\longrightarrow$ & n............... & ................ & n................ & \\
\hline Chlorite & n................ & n................ & - & $\longrightarrow$ & \\
\hline \multicolumn{6}{|l|}{ Albite } \\
\hline \multicolumn{6}{|l|}{ Actinolite } \\
\hline Clay & & & .................. & .................. & \\
\hline Carbonate & & & n............... & ................. & \\
\hline Magnetite & 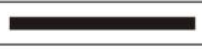 & .................. & & & \\
\hline Pyrite & 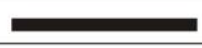 & ................ & n............... & - & \\
\hline Chalcopyrite & 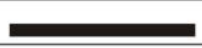 & .................. & n................ & .................. & \\
\hline Molybdenite & ................. & & & & \\
\hline Pyrrhotite & ................. & & & & \\
\hline Sphalerite & & & & (................... & \\
\hline Galena & & & & [................ & \\
\hline \multicolumn{6}{|l|}{ Chalcocite } \\
\hline Hematite & & & & & ................ \\
\hline limonite & & & & & ................. \\
\hline Malachite & & & & & (n.................. \\
\hline
\end{tabular}

Figure 5. Paragenetic relationships of the No.2 deposit in the Xiongcun district

\section{Sampling and analytical methods}

Samples of the Early Jurassic quartz diorite porphyry were collected from the drilling cores in the No.2 deposit (Fig. 1d). They have more or less intense hydrothermal alteration. In order to correctly characterize their chemical compositions, the least altered samples were subjected to whole-rock major, trace, rare-earth elements and $\mathrm{Sr}-\mathrm{Nd}-\mathrm{Pb}$ isotopes analyses.

The whole-rock major, trace and rare-earth element concentrations of the Early Jurassic quartz diorite porphyry samples were determined at the National Research Center for Geoanalysis, Beijing, China. Whole-rock major elements were analyzed using X-ray fluorescence (XRF). Powder samples with masses of approximately $0.5 \mathrm{~g}$ were mixed with $5 \mathrm{~g} \mathrm{Li}_{2} \mathrm{~B}_{4} \mathrm{O}_{7}$ to make glass disks, which were then analyzed on an 
AXIOS Minerals spectrometer. The accuracy of XRF analysis was within 5\%. Whole-rock trace elements including rare-earth elements (REEs) were analyzed using a Finnigan Element ICP-MS after the acid digestion of the samples in high-pressure Teflon bombs. The detailed analytical procedures are described in Qi et al. (2000), and the analytical precision was generally better than $5 \%$.

The whole-rock $\mathrm{Sr}-\mathrm{Nd}-\mathrm{Pb}$ isotopic analysis was performed using an IsoProbe-T thermal ionization mass spectrometer (TIMS) at the Analytical Laboratory of the Beijing Research Institute of Uranium Geology. The measured ${ }^{87} \mathrm{Sr} /{ }^{86} \mathrm{Sr}$ and ${ }^{143} \mathrm{Nd} /{ }^{144} \mathrm{Nd}$ ratios were normalized to ${ }^{86} \mathrm{Sr} /{ }^{88} \mathrm{Sr}=0.1194$ and ${ }^{146} \mathrm{Nd} /{ }^{144} \mathrm{Nd}=0.721900$, respectively. Herein, the ${ }^{87} \mathrm{Sr} /{ }^{86} \mathrm{Sr}$ ratios of the SRM NBS987 $\mathrm{Sr}$ standard and the ${ }^{143} \mathrm{Nd} /{ }^{144} \mathrm{Nd}$ ratio of the SHINESTU Nd standard were $0.710255 \pm 0.00004(2 \sigma)$ and $0.512116 \pm 0.00003$ $(2 \sigma)$, respectively. $\mathrm{Pb}$ was separated and purified using a conventional cation-exchange technique $\left(\mathrm{AG} 1 \times 8,200-400\right.$ resin) with diluted $\mathrm{HBr}$ as the eluant. The ${ }^{204} \mathrm{~Pb} /{ }^{206} \mathrm{~Pb}$, ${ }^{207} \mathrm{~Pb} /{ }^{206} \mathrm{~Pb}$, and ${ }^{208} \mathrm{~Pb} /{ }^{206} \mathrm{~Pb}$ ratios of the NBS981 $\mathrm{Pb}$ standard were $0.059043 \pm$ $0.000037(2 \sigma), 0.91465 \pm 0.00034(2 \sigma)$, and $2.1681 \pm 0.0005(2 \sigma)$, respectively.

Pyrite and chalcopyrite samples were selected from ores of the No.2 deposit to be analyzed for sulfur and lead isotope compositions. Sulfur isotope analyses were carried out using a MAT-251 EM mass spectrometer at the Analytical Laboratory, Beijing Research Institute of Uranium Geology. The detailed analytical methods used to obtain $\mathrm{SO}_{2}$ were described by Robinson and Kusakabe (1975) and Zhu et al. (2010). Sulfur isotope analyses were carried out using 200-mesh sulfides pure samples. They were combusted with $\mathrm{CuO}$ in an oven at $1000{ }^{\circ} \mathrm{C}$ and in vacuum condition. Liberated $\mathrm{SO}_{2}$ was frozen in a liquid nitrogen trap and after cryogenic separation from other gases. The results are expressed in the international standard CDT with analysis accuracy better than $\pm 0.2 \%$. Lead isotope analyses were performed using an IsoProbe- $T$ Thermal Ionization Mass Spectrometer (TIMS) also at Analytical Laboratory, Beijing Research Institute of Uranium Geology. The analytical procedures are similar with whole-rock lead analyses described by Leng et al. (2012). During the sample analysis, the international standard NBS981 was also measured as a sample. The ${ }^{208} \mathrm{~Pb} /{ }^{206} \mathrm{~Pb}$, ${ }^{207} \mathrm{~Pb} /{ }^{206} \mathrm{~Pb}$ and ${ }^{204} \mathrm{~Pb} /{ }^{206} \mathrm{~Pb}$ ratios of the Standard NBS981 measured in this study were $2.1680 \pm 0.0007(2 \sigma), 0.91465 \pm 0.00035(2 \sigma)$ and $0.059041 \pm 0.000035(2 \sigma)$, respectively.

Eight quartz samples were selected from the quartz - sulfide veins for oxygen and hydrogen isotope analysis. The oxygen and hydrogen isotopic compositions of the quartz were determined using a Finnigan-MAT 253 mass spectrometer at the Analytical Laboratory, Beijing Research Institute of Uranium Geology. The analytical method has been described by Zhu et al. (2010). Oxygen was liberated from quartz by reaction with $\mathrm{BrF}_{5}$ (Clayton and Mayeda, 1963) and converted to $\mathrm{CO}_{2}$ on a platinum-coated carbon rod. Hydrogen isotope ratios on bulk fluid inclusions in quartz were measured by mechanical crushing of about $5 \mathrm{~g}$ of quartz grains to $1-5 \mathrm{~mm}$ in size, according to the method described by Simon (2001). $\mathrm{H}_{2} \mathrm{O}$ was collected from quartz decrepitation under vacuum at $550{ }^{\circ} \mathrm{C}$ and then reduced by $\mathrm{Zn}$ at $400{ }^{\circ} \mathrm{C}$ to obtain $\mathrm{H}_{2}$. The released water was trapped, and then analyzed with a Finnigan Mat Delta $\mathrm{S}$ mass spectrometer MAT251 at the Analytical Laboratory, Beijing Research Institute of Uranium Geology. Analytical reproducibility is better than $\pm 0.2 \%$ o for $\delta^{18} \mathrm{O}, \pm 2 \%$ or $\delta \mathrm{D}$. $\delta^{18} \mathrm{O}_{\mathrm{H} 2 \mathrm{O}}$ was calculated according to oxygen isotope compositions of the quartz using the equilibrium fractionation equation $1000 \ln \alpha_{\text {Quartz-H2O }}=3.38 \times 10^{6} / \mathrm{T}^{2}-3.4$ (Clayton et al., 1972) and the $T_{h}$ peak values of fluid inclusions in the analyzed samples. 
In-situ zircon Hf isotopic analysis was carried out on zircon grains from the Early Jurassic quartz diorite porphyry that were previously analyzed for U-Pb isotopes by Lang et al. (2014a). Hf isotopes of those zircons were obtained using a Nu Plasma Multi-Collector MC-ICP-MS instrument, which is coupled to a $193 \mathrm{~nm}$ ArF Excimer laser-ablation system. The analytical method has been described by Tang et al. (2008) and He et al. (2013). The standard Mud Tank and TEMORA zircons used in this analysis. A laser repetition rate of $8 \mathrm{~Hz}$ at $20 \mathrm{~J} / \mathrm{cm}^{2}$ and a spot size of $44 \mu \mathrm{m}$ were used. The isobaric interference of ${ }^{176} \mathrm{Lu}$ on ${ }^{176} \mathrm{Hf}$ was corrected by measuring the intensity of the interference-free ${ }^{175} \mathrm{Lu}$ isotope and using the recommended ${ }^{176} \mathrm{Lu} /{ }^{175} \mathrm{Lu}$ ratio of 0.02669 (De Bievre and Taylor, 1993) to calculate ${ }^{176} \mathrm{Lu} /{ }^{177} \mathrm{Hf}$. The ${ }^{176} \mathrm{Yb} /{ }^{172} \mathrm{Yb}$ value of 0.5886 (Chu et al., 2002) and mean $\beta \mathrm{Yb}$ value obtained during a Hf analysis on the same spot were applied for the interference correction of ${ }^{176} \mathrm{Yb}$ on ${ }^{176} \mathrm{Hf}$ (Iizuka and Hirata, 2005). Initial ${ }^{176} \mathrm{Hf} /{ }^{177} \mathrm{Hf}$ ratios are calculated with reference to the chondritic reservoir (CHUR) at the time of zircon growth from the magma. A value for the decay constant of ${ }^{176} \mathrm{Lu}$ of $1.867 \times 10^{-11} \mathrm{yr}^{-1}$ (Söerlund et al., 2004) has been used in all calculations. For the calculations of $\varepsilon_{\mathrm{Hf}}$ values, we use chondritic ratios of ${ }^{176} \mathrm{Hf} /{ }^{177} \mathrm{Hf}=$ 0.282785 and ${ }^{176} \mathrm{Lu} /{ }^{177} \mathrm{Hf}=0.0336$ (Bouvier et al., 2008). Single-stage model ages $\left(\mathrm{T}_{\mathrm{DM} 1}\right)$ are calculated using the measured ${ }^{176} \mathrm{Lu} /{ }^{177} \mathrm{Hf}$ ratios, referred to a model depleted mantle with a present-day ${ }^{176} \mathrm{Hf} /{ }^{177} \mathrm{Hf}$ ratio of 0.28325 and ${ }^{176} \mathrm{Lu} /{ }^{177} \mathrm{Hf}=0.0384$ (Griffin et al., 2002). Two-stage model ages $\left(\mathrm{T}_{\mathrm{DM} 2}\right)$ are calculated for the source rock of the magma by assuming a mean ${ }^{176} \mathrm{Lu} /{ }^{177} \mathrm{Hf}$ value of 0.015 for the average continental crust (Griffin et al., 2002).

\section{Results}

\section{Whole rock major, trace and $\mathrm{REE}$ elements}

The major, trace and REE element data for the Early Jurassic quartz diorite porphyry are summarized in Table 1. The samples contain $\mathrm{SiO}_{2}$ range from 55.81 wt.\% to 67.32 wt. $\%, \mathrm{Na}_{2} \mathrm{O}$ range from 1.90 wt. $\%$ to 4.44 wt. $\%, \mathrm{~K}_{2} \mathrm{O}$ range from 1.87 wt.\% to 5.44 wt. $\%, \mathrm{MgO}$ range from $0.93 \mathrm{wt} . \%$ to $2.79 \mathrm{wt} . \%, \mathrm{Al}_{2} \mathrm{O}_{3}$ range from $14.71 \mathrm{wt} . \%$ to 19.74 wt. $\%, \mathrm{CaO}$ range from 0.68 wt. $\%$ to $5.76 \mathrm{wt} . \%$, and $\mathrm{TiO}_{2}$ range from 0.93 wt. $\%$ to 2.79 wt.\%. These samples plot mainly in the andesite (diorite) field of an $\mathrm{Nb} / \mathrm{Y}$ versus $\mathrm{Zr} / \mathrm{TiO}_{2}$ immobile element classification diagram (Fig. 6a) defined by Winchester and Floyd (1977). This whole-rock chemistry supports the mineral composition of the porphyry, which comprises palgioclase, hornblende and minor quartz. In the $\mathrm{Y}$ versus $\mathrm{Zr}$ diagram defined by Barrett and MacLean (1994) (Fig. 6b), all of the samples fall in the calc-alkaline and transitional fields and show that the porphyry has a transitional character from tholeiitic to calc-alkaline.

The porphyry is highly enriched in LREEs $\left((\mathrm{La} / \mathrm{Yb})_{\mathrm{N}}=3.33-7.92\right)$ and has relatively flat HREEs $\left((\mathrm{Gd} / \mathrm{Yb})_{\mathrm{N}}=1.26-1.69\right)$ patterns, with small negative Eu anomalies $\left(\mathrm{Eu} /{ }^{*} \mathrm{Eu}\right.$ =0.64-1.25) (Fig. 7a). The primitive mantle-normalized trace elements diagram (Fig. $7 b$ ) is characterized by large ion lithophile element (LILE, such as $\mathrm{K}, \mathrm{Rb}$ and $\mathrm{Ba}$ ) enrichments and high field strength element (HFSE, such as $\mathrm{Nb}, \mathrm{Ta}$, and Ti) depletions. 
Table 1. Analytical results of major (\%) and trace elements (ppm) for Early Jurassic quartz diorite porphyry of the No.2 deposit in the Xiongcun district

\begin{tabular}{|c|c|c|c|c|c|c|c|c|c|c|c|}
\hline $\begin{array}{l}\text { Sam- } \\
\text { ple }\end{array}$ & $\begin{array}{l}7224- \\
157.8\end{array}$ & $\begin{array}{l}7224- \\
419.6\end{array}$ & $\begin{array}{l}\text { 7226- } \\
238.7\end{array}$ & $\begin{array}{l}7229- \\
264.2\end{array}$ & $\begin{array}{l}7233- \\
163.7\end{array}$ & $\begin{array}{l}7232 \\
-436\end{array}$ & $\begin{array}{l}7239- \\
247.6\end{array}$ & $\begin{array}{l}\text { 7239- } \\
80\end{array}$ & $\begin{array}{l}\text { 7247- } \\
75.6\end{array}$ & $\begin{array}{l}7248- \\
360.4\end{array}$ & $\begin{array}{l}7251-3 \\
78.7\end{array}$ \\
\hline $\mathrm{SiO}_{2}$ & 59.17 & 62.76 & 67.32 & 66.50 & 55.81 & 62.0 & 67.23 & 66.29 & 64.45 & 63.91 & 66.48 \\
\hline $\mathrm{TiO}_{2}$ & 0.68 & 0.48 & 0.38 & 0.41 & 0.49 & 0.40 & 0.43 & 0.48 & 0.42 & 0.40 & 0.40 \\
\hline $\mathrm{Al}_{2} \mathrm{O}$ & 16.94 & 17.11 & 16.14 & 14.71 & 19.74 & 16.5 & 17.12 & 16.85 & 17.14 & 16.17 & 15.64 \\
\hline $\mathrm{Fe}_{2} \mathrm{O}$ & 3.78 & 1.02 & 1.71 & 3.07 & 4.35 & 1.69 & 1.68 & 2.03 & 1.93 & 1.53 & 1.27 \\
\hline $\mathrm{FeO}$ & 2.87 & 3.93 & 1.35 & 1.81 & 2.34 & 2.89 & 2.16 & 1.81 & 1.63 & 2.75 & 1.28 \\
\hline $\mathrm{MnO}$ & 0.08 & 0.13 & 0.07 & 0.07 & 0.06 & 0.18 & 0.04 & 0.05 & 0.04 & 0.08 & 0.03 \\
\hline $\mathrm{MgO}$ & 3.11 & 1.66 & 1.06 & 0.94 & 0.93 & 2.40 & 1.66 & 1.16 & 1.20 & 2.79 & 1.24 \\
\hline $\mathrm{CaO}$ & 4.22 & 4.79 & 3.82 & 2.99 & 3.74 & 5.76 & 0.68 & 3.31 & 4.26 & 4.40 & 3.04 \\
\hline $\mathrm{Na}_{2} \mathrm{O}$ & 3.12 & 3.14 & 2.66 & 1.90 & 4.56 & 2.97 & 3.10 & 2.52 & 3.54 & 2.96 & 4.44 \\
\hline $\mathrm{K}_{2} \mathrm{O}$ & 1.87 & 2.48 & 3.92 & 5.44 & 3.45 & 2.52 & 3.63 & 3.09 & 2.25 & 2.12 & 3.36 \\
\hline $\mathrm{P}_{2} \mathrm{O}_{5}$ & 0.22 & 0.19 & 0.11 & 0.14 & 0.10 & 0.11 & 0.12 & 0.19 & 0.12 & 0.12 & 0.18 \\
\hline LOI & 3.18 & 1.59 & 1.25 & 1.31 & 2.93 & 1.83 & 1.87 & 1.66 & 2.41 & 1.88 & 1.72 \\
\hline $\mathrm{La}$ & 19.20 & 15.00 & 10.00 & 6.98 & 11.80 & 9.35 & 11.00 & 9.89 & 10.20 & 15.80 & 14.90 \\
\hline $\mathrm{Ce}$ & 35.10 & 29.20 & 17.90 & 10.30 & 22.50 & 19.1 & 17.70 & 17.10 & 19.60 & 28.60 & 24.40 \\
\hline $\operatorname{Pr}$ & 4.00 & 3.40 & 2.12 & 1.58 & 2.88 & 2.18 & 2.39 & 2.29 & 2.60 & 3.16 & 3.07 \\
\hline $\mathrm{Nd}$ & 16.40 & 13.80 & 8.91 & 6.73 & 11.80 & 8.68 & 9.71 & 9.49 & 11.50 & 12.40 & 12.60 \\
\hline $\mathrm{Sm}$ & 3.43 & 3.02 & 1.98 & 1.54 & 2.87 & 1.85 & 1.99 & 2.12 & 3.03 & 2.59 & \\
\hline $\mathrm{Eu}$ & 1.10 & 0.90 & 0.74 & 0.60 & 0.95 & 0.84 & 0.59 & 0.48 & 1.03 & 0.74 & 0.72 \\
\hline $\mathrm{Gd}$ & 3.62 & 3.09 & 2.27 & 1.82 & 3.06 & 2.26 & 2.26 & & 3.80 & 2.86 & 2.82 \\
\hline $\mathrm{Tb}$ & 0.52 & 0.44 & 0.32 & 0.24 & 0.44 & 0.33 & 0.32 & 0.37 & 0.58 & 0.39 & 0.38 \\
\hline Dy & 2.90 & 2.56 & 1.90 & 1.43 & 2.63 & 2.10 & 2.06 & 2.2 & 3.52 & 2.37 & 2.19 \\
\hline Ho & 0.57 & 0.52 & 0.38 & 0.30 & 0.60 & 0.45 & 0.44 & 0.50 & 0.7 & 0.50 & 0.44 \\
\hline $\mathrm{Er}$ & 1.72 & 1.55 & 1.22 & 0.89 & 1.83 & 1.37 & 1.40 & 1.4 & 2.2 & 1.52 & 1.37 \\
\hline Tm & 0.24 & 0.24 & 0.18 & 0.14 & 0.29 & 0.20 & 0.20 & 0.23 & 0.33 & 0.23 & 0.20 \\
\hline $\mathrm{Yb}$ & 1.74 & 1.65 & 1.30 & 0.89 & 1.89 & 1.37 & 1.42 & 1.6 & 2.20 & 1.56 & 1.46 \\
\hline $\mathrm{Y}$ & 14.20 & 13.20 & 10.20 & 8.65 & 13.70 & 11.1 & 11.00 & 11.90 & 17.10 & 13.10 & 11.30 \\
\hline $\mathrm{Lu}$ & 0.27 & 0.26 & 0.21 & 0.16 & 0.31 & 0.22 & 0.21 & 0.27 & 0.33 & 0.24 & 0.22 \\
\hline $\mathrm{Li}$ & 55.00 & 20.20 & 29.50 & 22.00 & 15.10 & 33.4 & 36.80 & 26.50 & 20.70 & 44.80 & 5.58 \\
\hline $\mathrm{Be}$ & 1.16 & 1.24 & 0.93 & 0.70 & 0.96 & 1.14 & 0.86 & 0.94 & 1.05 & 0.89 & 1.14 \\
\hline $\mathrm{Sc}$ & 14.10 & 5.76 & 8.45 & 5.18 & 8.97 & 12.1 & 10.70 & 6.70 & 10.80 & 13.90 & 4.21 \\
\hline V & 151.0 & 77.40 & 75.60 & 119.0 & 138.0 & 155. & 109.0 & 107.0 & 108.0 & 117.0 & 62.10 \\
\hline $\mathrm{Cr}$ & 33.70 & 1.74 & 9.73 & 3.10 & 5.31 & 4.22 & 10.20 & 11.80 & 11.10 & 12.80 & 1.91 \\
\hline $\mathrm{Co}$ & 22.90 & 14.60 & 4.78 & 18.10 & 28.20 & 11.0 & 8.12 & 3.53 & 12.20 & 7.52 & 4.57 \\
\hline $\mathrm{Ni}$ & 10.50 & 2.26 & 4.1 & & 7.89 & 4.27 & 4.5 & 4.6 & 4.70 & 7.51 & 57.30 \\
\hline $\mathrm{Cu}$ & 855.0 & 947.0 & & & & & 1628. & 1377. & & & 425.00 \\
\hline $\mathrm{Zn}$ & 108.0 & 112.0 & 119.0 & 73.40 & 53.90 & 647 & 30.30 & 61.30 & 44.80 & 85.80 & 20.60 \\
\hline $\mathrm{Ga}$ & & & & & & & & & & & \\
\hline $\mathrm{Rb}$ & 39.20 & 39.20 & 77.80 & 76. & 54.80 & 40.0 & 104.0 & 53.30 & 84.80 & 78.30 & 58.60 \\
\hline $\mathrm{Sr}$ & 293.0 & & & & & & & & & & 288.00 \\
\hline $\mathrm{Zr}$ & 71.70 & 91.50 & 98.30 & 85.40 & 108.0 & 88.8 & 72.90 & 105.0 & 85.60 & 78.20 & 90.10 \\
\hline $\mathrm{Nb}$ & & 7.34 & 5.47 & & 5.97 & & 5.25 & & 5.9 & & \\
\hline Mo & 7.99 & 0.93 & 3.00 & 443.0 & 3.84 & 4.35 & 1.30 & 8.70 & 2.82 & 102.0 & 245.00 \\
\hline Cs & 4.83 & 3.01 & 3.11 & & 3.15 & & 11.10 & 3.40 & & 4.67 & \\
\hline $\mathrm{Ba}$ & 170.0 & 323.0 & 800.0 & 609.0 & 549.0 & 331. & 313.0 & 497.0 & 180.0 & 220.0 & 488.00 \\
\hline $\mathrm{Hf}$ & 2.04 & 2.47 & 2.53 & & & & 2.06 & 2.89 & 2.40 & 2.09 & \\
\hline $\mathrm{Ta}$ & 0.49 & 0.44 & 0.40 & 0.43 & 0.45 & 0.40 & 0.39 & 0.53 & 0.44 & 0.37 & 0.49 \\
\hline W & & & & & & & 0.7 & & 1.11 & & 1.38 \\
\hline $\mathrm{Pb}$ & 11.80 & 47.00 & 9.81 & 13.40 & 10.60 & 178. & 7.04 & 11.60 & 13.10 & 7.3 & 5.41 \\
\hline $\mathrm{Bi}$ & & 0.55 & 0.12 & 0.17 & 1.08 & 0.48 & 0.08 & 0.05 & 0.15 & 0.1 & 0.10 \\
\hline Th & 4.82 & 4.57 & 4.73 & 6.32 & 4.89 & 3.65 & 3.85 & 5.20 & 3.68 & 3.71 & 5.59 \\
\hline $\mathrm{U}$ & 1.79 & 1.34 & 4.32 & & 4.86 & & 3.33 & 1.09 & 1.83 & 1.08 & 1.39 \\
\hline (La/ & 7.92 & 6.52 & 5.52 & 5.63 & 4.48 & 4.90 & 5.56 & 4.35 & 3.33 & 7.26 & 7.32 \\
\hline$\delta \mathrm{Eu}$ & 0.95 & 0.89 & 1.06 & 1.09 & 0.97 & 1.25 & 0.85 & 0.64 & 0.93 & 0.83 & 0.81 \\
\hline
\end{tabular}



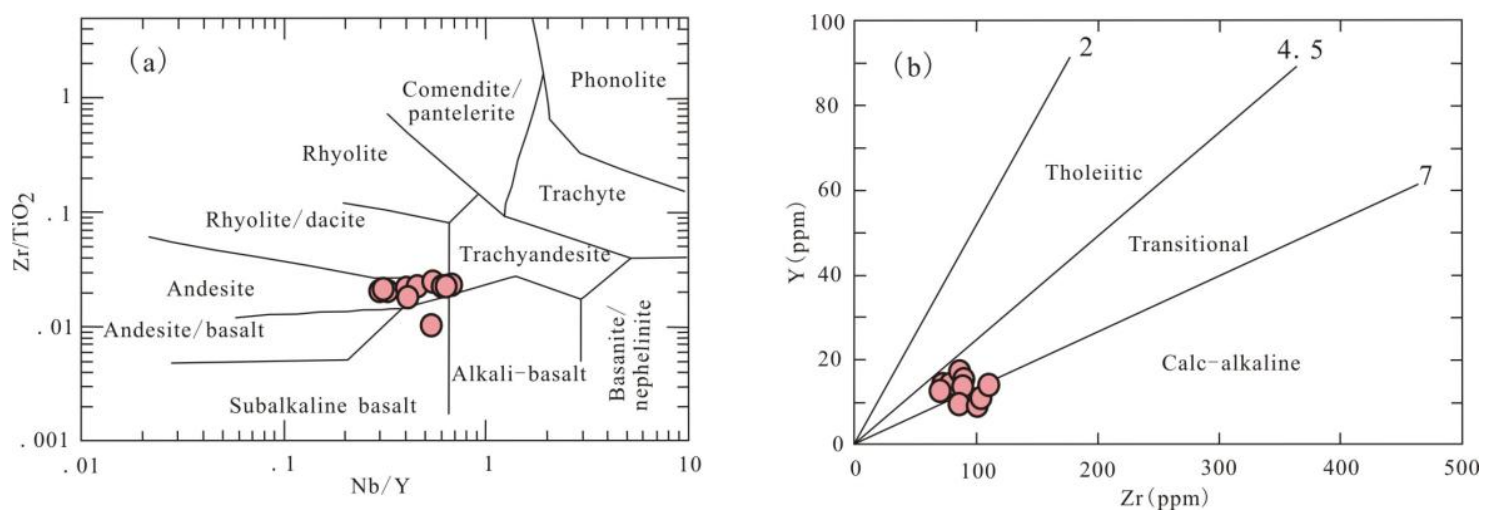

Figure 6. Diagrams for Early Jurassic quartz diorite porphyry of the No.2 deposit in the Xiongcun district. (a) $\mathrm{Nb} / \mathrm{Y}$ versus $\mathrm{Zr} / \mathrm{TiO} \mathrm{O}_{2}$ classification diagram after Winchester and Floyd (1977). (b) Zr versus Y discrimination diagram after Barrett and MacLean (1994)
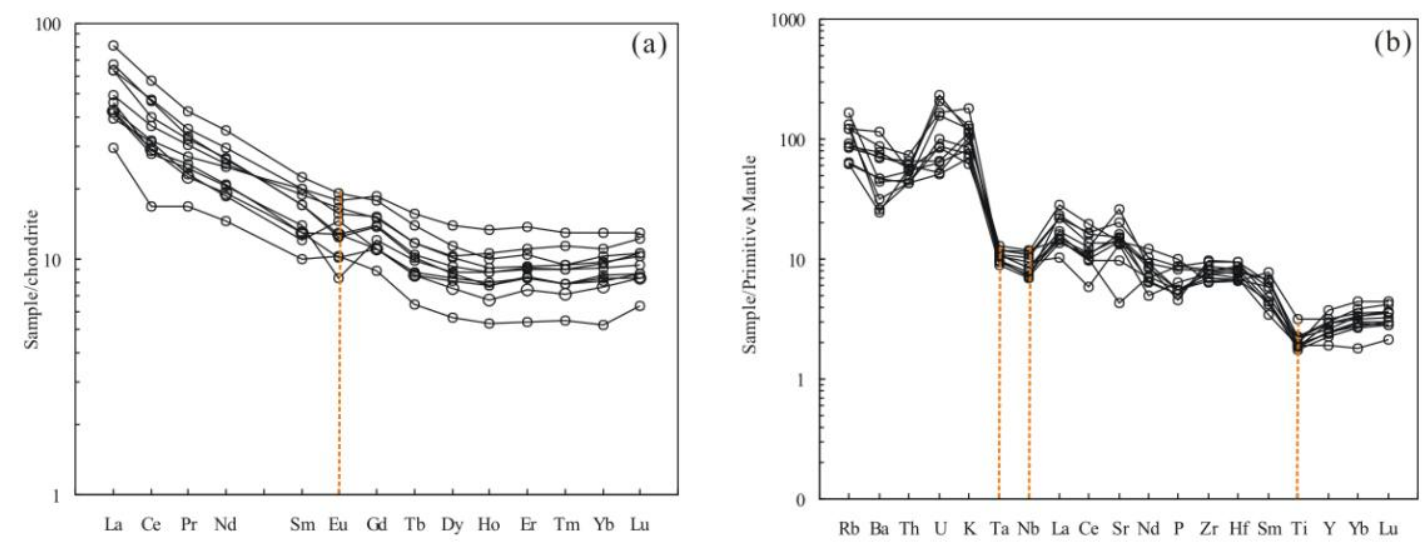

Figure 7. Chondrite-normalized REE diagram (a) and primitive mantle-normalized trace element diagram (b) for Early Jurassic quartz diorite porphyry of the No.2 deposit in the

Xiongcun district. Chondrite and primitive mantle data are from Sun and McDonough (1989)

\section{Sulphide sulfur and lead isotopes}

The $\delta^{34} \mathrm{~S}$ of pyrite and chalcopyrite from the No.2 deposit (Table 2) homogeneous with $\delta^{34} \mathrm{~S}$ values ranging from $-2.4 \%$ to $+1.2 \%$ with an average of $0.06 \%$. The porphyry has a similar $\delta^{34} \mathrm{~S}$ range of $-1.6 \%$ to $-0.6 \%$ with an average of $-1.3 \%$ (Table 2 ).

As shown in Table 2, sulfides (such as pyrite and chalcopyrite) have uniform, weakly radiogenic $\mathrm{Pb}$ isotope compositions. Their $\mathrm{Pb}$ isotope ratios range from 17.972 to 18.425 for ${ }^{206} \mathrm{~Pb} /{ }^{204} \mathrm{~Pb}, 15.528$ to 15.593 for ${ }^{207} \mathrm{~Pb} /{ }^{204} \mathrm{~Pb}$ and 38.024 to 38.489 for ${ }^{208} \mathrm{~Pb} /{ }^{204} \mathrm{~Pb}$. The $\mu$ values of ore sulfides vary from 9.34 to 9.49 with an average of 9.40 .

\section{Whole rock $\mathrm{Sr}-\mathrm{Nd}-\mathrm{Pb}$ isotopes}

The $\mathrm{Sr}, \mathrm{Nd}$ and $\mathrm{Pb}$ isotope results for the Early Jurassic quartz diorite porphyry are given in Table 3. The $\left({ }^{87} \mathrm{Sr} /{ }^{86} \mathrm{Sr}\right)_{\mathrm{i}}$ and $\varepsilon_{\mathrm{Nd}}(\mathrm{t})$ values are calculated at the age of $179 \mathrm{Ma}$ (zircon U-Pb ages; Lang et al., 2014a). The calculated $\left({ }^{87} \mathrm{Sr} /{ }^{86} \mathrm{Sr}\right)_{\mathrm{i}}$ values range from 0.70400 to 0.70509 with an average of 0.70442 . The calculated $\varepsilon_{\mathrm{Nd}}(\mathrm{t})$ ratios vary from 
5.45 to 5.94 with an average of 5.75 , and one-stage $\mathrm{Nd}$ model ages $\left(\mathrm{T}_{\mathrm{DM} 1}\right)$ range from 494 to $669 \mathrm{Ma}$ and two-stage $\mathrm{Nd}$ model ages $\left(\mathrm{T}_{\mathrm{DM} 2}\right.$ ) between $481 \mathrm{Ma}$ and $520 \mathrm{Ma}$. These samples have similar $\mathrm{Pb}$ isotope compositions (Table 3). Their $\mathrm{Pb}$ isotopic ratios vary from 18.460 to 18.857 for ${ }^{206} \mathrm{~Pb} /{ }^{204} \mathrm{~Pb}$, from 15.573 to 15.622 for ${ }^{207} \mathrm{~Pb} /{ }^{204} \mathrm{~Pb}$ and from 38.577 to 38.948 for ${ }^{208} \mathrm{~Pb} /{ }^{204} \mathrm{~Pb}$, respectively.

Table 2. Lead and sulfur isotopic data for ore sulfides and by Early Jurassic quartz diorite porphyry from the No.2 deposit in the Xiongcun district

\begin{tabular}{|c|c|c|c|c|c|c|}
\hline Sample & Sample description & ${ }^{206} \mathrm{~Pb} /{ }^{204} \mathrm{~Pb}$ & ${ }^{7} \mathbf{P b} /{ }^{204} \mathbf{P b}$ & ${ }^{8} \mathbf{P b} /{ }^{204} \mathbf{P b}$ & $\mu$ & $\begin{array}{c}\delta^{34} S \\
\text { CDT\%o } \\
\end{array}$ \\
\hline $7227-341.4$ & Pyrite from potassic alteration zone & 18.150 & 15.561 & 38.261 & 9.42 & 1.0 \\
\hline 7229-187.9 & Pyrite from chlorite-sericite alteration zone & - & - & - & - & 1.2 \\
\hline $7229-456.1$ & Pyrite from potassic alteration zone & 17.972 & 15.528 & 38.024 & 9.37 & 1.1 \\
\hline $7232-269.3$ & $\begin{array}{l}\text { Pyrite from zone of sodic-calcic alteration } \\
\text { overprint potassic alteration }\end{array}$ & 18.273 & 15.555 & 38.295 & 9.39 & -1.6 \\
\hline $7232-351$ & $\begin{array}{l}\text { Pyrite from zone of sodic-calcic alteration } \\
\text { overprint potassic alteration }\end{array}$ & 18.030 & 15.593 & 38.398 & 9.49 & -1.4 \\
\hline $7239-387.4$ & Pyrite from chlorite-sericite alteration zone & 18.341 & 15.543 & 38.335 & 9.36 & -0.7 \\
\hline $7239-485.6$ & Pyrite from potassic alteration zone & 18.135 & 15.575 & 38.383 & 9.45 & 1.0 \\
\hline $7227-341.4$ & Chalcopyrite from potassic alteration zone & 18.415 & 15.570 & 38.487 & 9.40 & 0.7 \\
\hline $7229-187.6$ & $\begin{array}{l}\text { Chalcopyrite from chlorite-sericite } \\
\text { alteration zone }\end{array}$ & 18.301 & 15.559 & 38.381 & 9.39 & 0.3 \\
\hline $7239-485.6$ & Chalcopyrite from potassic alteration zone & 18.425 & 15.567 & 38.489 & 9.40 & 1.0 \\
\hline 7239-387.4 & $\begin{array}{l}\text { Chalcopyrite from chlorite-sericite } \\
\text { alteration zone }\end{array}$ & 18.327 & 15.532 & 38.305 & 9.34 & 0.5 \\
\hline $7246-495.1$ & Chalcopyrite from potassic alteration zone & 18.319 & 15.569 & 38.428 & 9.41 & -2.4 \\
\hline $7224-159.8$ & Early Jurassic quartz diorite porphyry & \multicolumn{4}{|c|}{ See table 3} & -0.6 \\
\hline $7226-238.9$ & Early Jurassic quartz diorite porphyry & \multicolumn{4}{|c|}{ See table 3} & -1.6 \\
\hline $7229-264.2$ & Early Jurassic quartz diorite porphyry & \multicolumn{3}{|c|}{ See table 3} & & -1.6 \\
\hline
\end{tabular}

\section{Oxygen and hydrogen isotopes}

Oxygen and hydrogen isotope data determined from quartz in the quartz - sulfide veins are shown in Table 4. The $\delta^{18} \mathrm{O}_{\text {quartz }}$ and $\delta^{18} \mathrm{D}_{\mathrm{H} 2 \mathrm{O}}$ values range from +5.9 to $+10.7 \%$ and -104.0 to $-57.5 \%$, respectively. The peak value of homogenization 
temperatures for each sample were used to calculated $\delta^{18} \mathrm{O}$ values of the hydrothermal fluid using the fractionation expression $\left(1000 \ln \alpha_{\text {Quartz-H2O }}=3.38 \times 10^{6} / \mathrm{T}^{2}-3.4\right)$ of Clayton et al. (1972). The $\delta^{18} \mathrm{O}_{\mathrm{H} 2 \mathrm{O}}$ values were calculated to range from -5.5 to $+2.9 \%$ o (Table 4).

Table 3. Sr-Nd-Pb isotopic compositions of the Early Jurassic quartz diorite porphyry from the No.2 deposit in the Xiongcun district

\begin{tabular}{cccccccc}
\hline Sample & 7224-159. & $\mathbf{7 2 2 6 - 2 3 8}$. & $\mathbf{7 2 2 9 - 2 6 4}$ & $\mathbf{7 2 3 2 - 4 3}$ & $\mathbf{7 2 3 3 - 1 6 3 .}$ & $\mathbf{7 2 3 9 - 2 4 7 .}$ & $\mathbf{7 2 4}$ \\
\hline${ }^{87} \mathrm{Rb} /{ }^{86} \mathrm{Sr}$ & 0.5449 & 0.7673 & 0.7466 & 0.3381 & 0.2888 & - & - \\
${ }^{87} \mathrm{Sr} /{ }^{86} \mathrm{Sr}$ & 0.70578 & 0.70614 & 0.70590 & 0.70526 & 0.705826 & - & - \\
$\left.{ }^{87} \mathrm{Sr} /{ }^{86} \mathrm{Sr}\right)_{\mathrm{i}}$ & 0.70439 & 0.70419 & 0.70400 & 0.70441 & 0.70509 & - & - \\
${ }^{147} \mathrm{Sm} /{ }^{144} \mathrm{Nd}$ & 0.1222 & 0.1125 & 0.1478 & 0.1288 & 0.1470 & - & - \\
${ }^{143} \mathrm{Nd} /{ }^{144} \mathrm{Nd}$ & 0.512855 & 0.512841 & 0.512868 & 0.51285 & 0.512859 & - & - \\
$\left({ }^{143} \mathrm{Nd} /{ }^{144} \mathrm{Nd}\right)$ & 0.512712 & 0.512709 & 0.512695 & 0.51270 & 0.512687 & - & - \\
$\varepsilon_{\mathrm{Nd}}(\mathrm{t})$ & 5.94 & 5.89 & 5.61 & 5.85 & 5.45 & - & - \\
$\mathrm{T}_{\mathrm{DM} 1}(\mathrm{Ma})$ & 494 & 468 & 656 & 527 & 669 & - & - \\
$\mathrm{T}_{\mathrm{DM} 2}(\mathrm{Ma})$ & 481 & 485 & 508 & 488 & 520 & - & - \\
${ }^{206} \mathrm{~Pb} /{ }^{204} \mathrm{~Pb}$ & 18.560 & 18.522 & 18.460 & 18.498 & 18.857 & 18.516 & 18.6 \\
${ }^{207} \mathrm{~Pb} /{ }^{204} \mathrm{~Pb}$ & 15.622 & 15.607 & 15.586 & 15.573 & 15.612 & 15.573 & 15.5 \\
${ }^{208} \mathrm{~Pb} /{ }^{204} \mathrm{~Pb}$ & 38.727 & 38.670 & 38.603 & 38.584 & 38.948 & 38.577 & 38.6 \\
\hline
\end{tabular}

Note: (1) - no analyses; (2) $\varepsilon_{\mathrm{Nd}}(\mathrm{t})$ values are calculated using present-day $\left({ }^{147} \mathrm{Sm} /{ }^{144} \mathrm{Nd}\right) \mathrm{CHUR}=0.1967$ and $\left({ }^{143} \mathrm{Nd} /{ }^{144} \mathrm{Nd}\right) \mathrm{CHUR}=0.512638 ;$ (3) TDM values are calculated using present-day $\left({ }^{147} \mathrm{Sm} /{ }^{144} \mathrm{Nd}\right) \mathrm{DM}=0.2137$ and $\left({ }^{143} \mathrm{Nd} /{ }^{144} \mathrm{Nd}\right) \mathrm{DM}=0.51315$.

\section{In situ zircon Hf isotopes}

The Zircon Lu - Hf isotopic results of the Early Jurassic quartz diorite porphyry are listed in Table 5. The initial Hf ratios of the analyzed zircon grains were calculated on the basis of the previously measured ${ }^{206} \mathrm{~Pb} /{ }^{238} \mathrm{U}$ age, respectively. Thirty two analyses were made on 32 zircon grains from Samples 7226-233.7, 7224-159.9 and 7235-123.4. The calculated $\varepsilon_{\mathrm{Hf}}(\mathrm{t})$ values vary from +11.83 to +16.87 with an average value of + 14.14 (Table 5). Their corresponding single-stage Hf model ages $\left(\mathrm{T}_{\mathrm{DM} 1}\right)$ vary from 142.92 Ma to 339.85 Ma with an average of 249.329 Ma and Two-stage Hf model ages ( $\mathrm{T}_{\mathrm{DM} 2}$ ) range from 119.10 Ma to 436.73 Ma with an average of 290.62 Ma (Table 5).

\section{Discussion}

\section{Timing of the magmatism and mineralization}

The rock- and ore-forming ages of the No.2 deposit in the Xiongcun district have recently been precisely constrained. Three samples (7226-233.7, 7224-159.9 and 7235-123.4) from the Early Jurassic quartz diorite porphyry yielded zircon U-Pb weighted average ages of $181.8 \pm 1.5 \mathrm{Ma}, 175.7 \pm 1.5 \mathrm{Ma}$ and $179 \pm 2 \mathrm{Ma}$, respectively, interpreted as the magmatic crystallization age of the porphyry (Lang et al., 2014a). Lang et al. (2014a) also obtained a Re-Os weighted average age of $172.6 \pm 2.1 \mathrm{Ma}$ from molybdenite of the No.2 deposit, interpreted as the age of ore formation. In addition, Tafti et al. (2009) obtained a molybdenite Re-Os age of $174.2 \pm 0.2 \mathrm{Ma}$ in the No.2 
deposit, which is in consistent with molybdenite Re-Os weighted average age of $172.6 \pm$ 2.1 Ma obtained by Lang et al.( 2014a). These data show that the mineralization of the No.2 deposit in the Xiongcun district occurred at $172.6 \pm 2.1 \mathrm{Ma}$, shortly after the intrusion of the porphyry at 181-175 Ma.

Table 4. $\delta^{18} O$ and $\delta D$ of quartz from the quartz-sulfide veins of the No.2 deposit in the Xiongcun district

\begin{tabular}{|c|c|c|c|c|c|}
\hline Samples & Sample description & $\begin{array}{l}\mathbf{T}_{\mathbf{h}} \\
\left({ }^{\circ} \mathrm{C}\right) \\
\end{array}$ & $\begin{array}{c}\delta D_{\mathrm{H} 2 \mathrm{O}} \\
(\%, \text { SMOW })\end{array}$ & $\begin{array}{c}\delta^{18} \mathbf{O}_{\text {Quartz }} \\
(\%, \text { SMOW) }\end{array}$ & $\begin{array}{c}\delta^{18} \mathrm{O}_{\mathrm{H} 20} \\
(\%, \text { SMOW })\end{array}$ \\
\hline $7223-353$ & $\begin{array}{l}\text { Quartz from quartz - sulfide } \\
\text { vein }\end{array}$ & 267 & -74.8 & 9.8 & 1.6 \\
\hline 7226-136.6 & $\begin{array}{l}\text { Quartz from quartz - sulfide } \\
\text { vein }\end{array}$ & 268 & -96.6 & 10.1 & 2.0 \\
\hline $7229-153.3$ & $\begin{array}{l}\text { Quartz from quartz - sulfide } \\
\text { vein }\end{array}$ & 192 & -79.9 & 10.7 & -1.5 \\
\hline $7231-215.7$ & $\begin{array}{l}\text { Quartz from quartz - sulfide } \\
\text { vein }\end{array}$ & 256 & -80.5 & 8.4 & -0.3 \\
\hline $7233-164.8$ & $\begin{array}{l}\text { Quartz from quartz - sulfide } \\
\text { vein }\end{array}$ & 303 & -66.3 & 9.7 & 2.9 \\
\hline $7238-591$ & $\begin{array}{l}\text { Quartz from quartz - sulfide } \\
\text { vein }\end{array}$ & 204 & -104.0 & 5.9 & -5.5 \\
\hline $7250-209.1$ & $\begin{array}{l}\text { Quartz from quartz - sulfide } \\
\text { vein }\end{array}$ & 216 & -57.5 & 10.2 & -0.5 \\
\hline $7250-267.3$ & $\begin{array}{c}\text { Quartz from quartz - sulfide } \\
\text { vein }\end{array}$ & 276 & -59.8 & 6.2 & -1.6 \\
\hline
\end{tabular}

Note: (1) $\delta^{18} \mathrm{O}_{\mathrm{H} 2 \mathrm{O}}$ was calculated with $1000 \ln \alpha_{\text {Quartz-H2O }}=3.38 \times 10^{6} / \mathrm{T}^{2}-3.4$ (Clayton et al., 1972) from the $\delta^{18} \mathrm{O}$ of the quartz; (2) $\mathrm{T}_{\mathrm{h}}$ is the peak value of homogenization temperatures of the fluid inclusions.

\section{Geodynamic setting}

The Xiongcun district is located in the southern margin of the Lasha terrane, which have experienced subduction of the Neo-Tethys oceanic plate and Indian - Asian continental collision. The timing of Neo-Tethys subduction is controversial. Previous study showed that the northward subduction of the Neo-Tethys oceanic plate probably started in the Late Jurassic (Honegger et a1., 1982; Pearce and Mei, 1988; Zhu et al., 2009). However, voluminous Late Triassic - Jurassic magmatism has been discovered along the southern margin of the Lhasa terrane (Chu et al., 2006; Zhu et al., 2008; Ji et al., 2009; Guo et al., 2013; Tafti et al., 2009; Lang et al., 2014a) suggests that the subduction began in the Late Triassic - Jurassic or earlier (Mo et al. 2005; Chu et al., 2006, 2011; Ji et al., 2009; Zhang et al., 2007; Guo et al., 2013; Lang et al., 2014a).

The Early Jurassic quartz diorite porphyry has strong LREEs enrichment and HREEs depletion with slightly negative Eu anomalies (Fig. 7a). They also exhibit considerable enrichment in LILEs and negative $\mathrm{Nb}$ and Ta anomalies (Fig. 7b). These features suggest an affinity with magmas generated in a subduction-related tectonic setting (Wood et al., 1979; Briqueu et al., 1984; Rollinson, 1993; Lan et al., 1996). Moreover, in the $(\mathrm{Y}+\mathrm{Nb})$ versus $\mathrm{Rb}$ and $\mathrm{Yb}$ versus Ta diagrams (Pearce et al., 1984; Fig. 8), samples plot within the domains of volcanic arc granite. The subduction-related Early Jurassic quartz diorite porphyry of this study intruded the southern margin of the Lhasa terrane during the Early Jurassic. This arc magmatism is much older than India - Asia collision which began in the Paleocene (Mo et al., 2005; Ding et al., 2005) but is consistent with the epoch of the northward subduction of Neo-Tethys. Thus, we 
consider that the porphyry probably resulted from the northward subduction of the Neo-Tethys oceanic slab.

Table 5. Hf isotope analyses for zircon of Early Jurassic quartz diorite porphyry from NO.2 deposit in the Xiongcun district

\begin{tabular}{|c|c|c|c|c|c|c|c|c|c|c|}
\hline Spot & & $\pm 2 \delta$ & ${ }^{176} \mathbf{L u} /{ }^{177}$ & $\pm 2 \delta$ & ${ }^{176} \mathrm{Hf} /{ }^{177}$ & $\pm 2 \delta$ & Age & $\varepsilon_{\mathrm{Hf}}$ & & \\
\hline \multicolumn{11}{|c|}{ Sample 7226-233.7 } \\
\hline 1.1 & 0.070048 & 0.000354 & 001877 & & 0.283079 & & 181. & 14.2 & 49.02 & 287.17 \\
\hline 2.1 & 0.037790 & 000160 & 001047 & 000004 & 0.283026 & .000018 & 174. & 12.3 & 19.67 & 406.24 \\
\hline 3.1 & 0.047385 & & 0.001283 & 0.000008 & 0.283045 & 0.000021 & 184. & 13.1 & & \\
\hline 4.1 & 0.036443 & & 0.001010 & 0.000010 & 0.283052 & & 177. & 13.2 & & \\
\hline 5.1 & & & & & 0.283035 & & 187. & 12.8 & 0.03 & 81.02 \\
\hline 6.1 & 0.043959 & 0.000902 & 0.001497 & 000039 & 0.283151 & 0.000027 & 184. & 16.8 & 142.92 & 19.10 \\
\hline 7.1 & 0.056755 & 0.000 & 0.001386 & 000010 & 0.283106 & 0.000022 & 181. & 15.2 & & 23.15 \\
\hline 8.1 & 0.0403 & & 0.0010 & 19 & 0.283064 & & 180. & 13.7 & & 6.94 \\
\hline 9.1 & 0.047410 & 0.000 & 0.001 & 14 & 0.2831 & 0.000024 & 187. & 16.2 & & \\
\hline 10.1 & 0.042736 & & 0.00 & & 0.28 & & 180. & 13.9 & & \\
\hline 11.1 & 0.057008 & & 0.00 & & 0.28 & & 184. & 13.8 & & \\
\hline 12.1 & 0.064720 & & 0.00 & & 0.28 & & 77. & 1.5 & & 263.07 \\
\hline 13. & 0.052728 & 0.000118 & 0.001403 & 000009 & 0.283047 & 0.000024 & 178. & 13.0 & & \\
\hline & 0.04 & & 0.00 & & 0.28 & & 175. & 13.5 & & \\
\hline & 0.04 & & & & 0.2 & & 183. & 12.0 & & 432.67 \\
\hline 16.1 & 0.064175 & & 0.00 & & 0.28 & & 181. & 13.6 & & \\
\hline \multicolumn{11}{|c|}{ Sample 7224-159.9 } \\
\hline 1.1 & & & & & & & & & & \\
\hline 2.1 & 0.032 & & 0.0 & & 0.28 & & 176. & 14.5 & & \\
\hline 3.1 & 0.046481 & 0.00 & 0.001 & 07 & 0.28 & 18 & 177. & 13.7 & 262.73 & 312.96 \\
\hline 4.1 & 0.049078 & & 0.001 & & 0.28 & & 176. & 13.9 & & 301.15 \\
\hline 5.1 & 0.040206 & 0.00 & 0.001127 & 0.000 & 0.283 & & 174. & 14.6 & & 7.16 \\
\hline 6.1 & 0.041611 & & 0.00 & 0.00 & 0.28 & 025 & 176. & 14.7 & & 47.91 \\
\hline 7.1 & 0.044837 & & 0.001 & & 0.283074 & 0026 & 75. & 14.0 & & 295.98 \\
\hline 8.1 & 0.044272 & 0.000 & 0.001042 & 0.0000 & 0.28 & 0.0000 & 176. & 16.3 & 158.20 & 147.46 \\
\hline 9.1 & 0.038005 & 0.0001 & 0.001124 & 0.000003 & 0.283089 & 0.000022 & 171. & 14.4 & 230.41 & 265.41 \\
\hline 11. & 0.044389 & 0.000 & 0.0014 & 0.000012 & 0.283075 & & 176. & 14.0 & & 296.13 \\
\hline & 0.030404 & & 0.00 & 13 & 0.28 & 0.000018 & 175. & 11.8 & & \\
\hline 13.1 & 0.052748 & 0.000475 & 0.001428 & 0.000006 & 0.283076 & 0.000022 & 174. & 14.0 & 250.91 & 295.06 \\
\hline \multicolumn{11}{|c|}{ Sample 7235-123.4 } \\
\hline 1.1 & & & & & & & 176. & 13.9 & & \\
\hline & & & & & 0.28 & & 177. & 16.2 & & 156.29 \\
\hline 5.1 & & & & & 0.283 & & 175. & 16.0 & & 166.83 \\
\hline 11.1 & 0.092354 & 0.001648 & 0.002593 & 0.000015 & 0.283066 & 0.000023 & 178. & 13.6 & 273.35 & 323.53 \\
\hline
\end{tabular}

Note: Ages are from zircon ${ }^{206} \mathrm{~Pb} /{ }^{238} \mathrm{U}$ ages analyzed by Lang et al., 2014a.

Previous discussions concerning the geodynamic setting of the Late Triassic Jurassic magmatic rocks in the southern margin of the Lhasa terrane are controversial. Some studies indicate that these rocks formed in a continental margin arc setting (Zhu et 
al., 2008; Guo et al., 2013; Kang et al., 2014) and others suggest that they formed in an intra-oceanic island arc setting (Chu et al., 2011; Lang et al., 2014a).
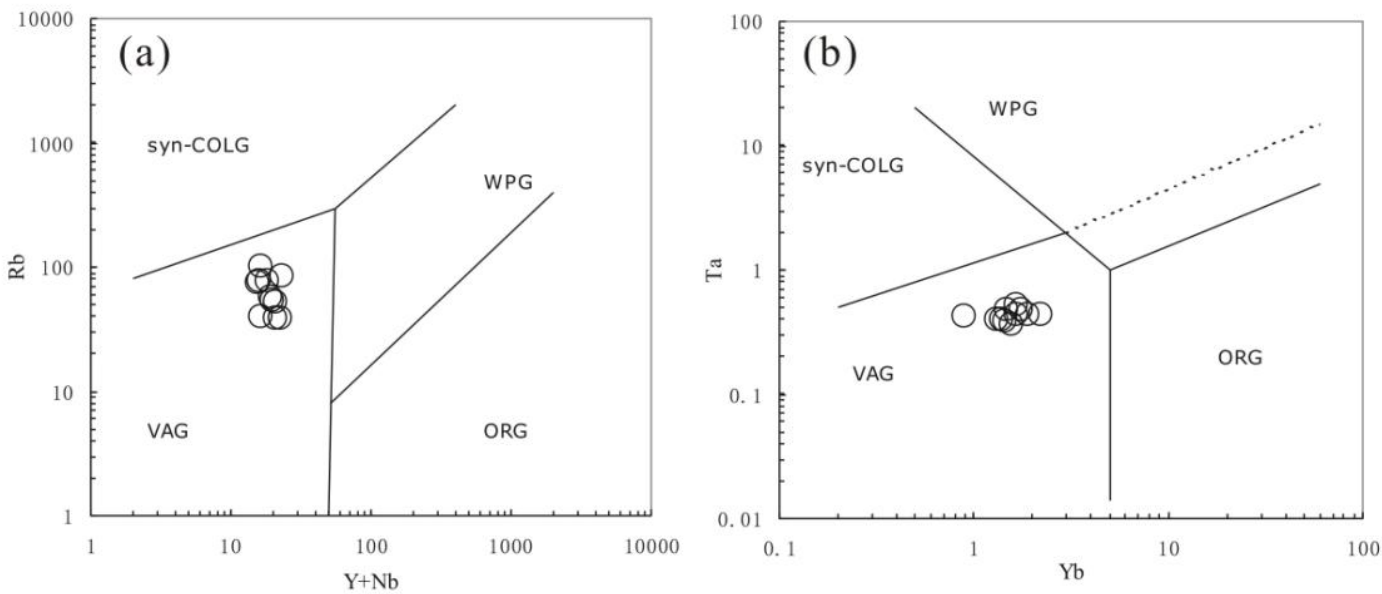

Figure 8. The trace elements tectonic setting plots of the Early Jurassic quartz diorite porphyry from the No.2 deposit in the Xiongcun district (after Pearce et al., 1984). VAG = Volcanic arc granite; syn-COLG = Syn-collision granite; $W P G=$ Within plate granite; and $O R G=$ Ocean ridge granite

Early Jurassic quartz diorite porphyry from the No.2 deposit in the Xiongcun district has high and positive $\varepsilon_{\mathrm{Nd}}(\mathrm{t})$ and $\varepsilon_{\mathrm{Hf}}(\mathrm{t})$ values with low $\mathrm{Nd}$ and $\mathrm{Hf}$ model ages similar to magmatic rocks from intra-oceanic island arcs (Ravikant et al., 2009; Schaltegger et al., 2002; Todd et al., 2012; Marini, et al., 2005). Moreover, an intra-oceanic subduction system has been recognized within the Yarlung-Zangbo suture zone (Aitchison et al., 2000; McDermid et al., 2002, Dai et al., 2011). On the other hand, the porphyry from the No.2 deposit has calc-alkaline to transitional compositions (Fig. 6). Calc-alkaline rocks are typical constituents of mature island arcs (Shen et al., 2009), whereas tholeiitic rocks may be associated with emerging island arcs (e.g. Kuno, 1966; Miyashiro, 1974), mid-ocean ridges, and backarc-basin spreading centers (e.g. Gill, 1976). In the ${ }^{206} \mathrm{~Pb} /{ }^{204} \mathrm{~Pb}$ versus ${ }^{207} \mathrm{~Pb} /{ }^{204} \mathrm{~Pb}$ and ${ }^{206} \mathrm{~Pb} /{ }^{204} \mathrm{~Pb}$ versus ${ }^{208} \mathrm{~Pb} /{ }^{204} \mathrm{~Pb}$ tectonic discrimination diagrams (Fig. 9), all the samples except one (7233-163.7) plot in the transition zone of primitive arc (oceanic island volcanic rock) and mature arc. In the Th versus $\mathrm{La} / \mathrm{Yb}$ and $\mathrm{Sc} / \mathrm{Ni}$ versus $\mathrm{La} / \mathrm{Yb}$ diagrams (Fig. 10), samples of the porphyry plot in the field of transition zone of oceanic island arc and continental island arc fields.

In summary, we suggest that the No.2 deposit formed in an intra-oceanic island arc setting with transitional features from mature intra-oceanic island arc to continental island arc, which was probably related to the northward intra-oceanic subduction of the Neo-Tethys oceanic slab.

\section{Petrogenesis of the porphyry}

The relative robustness of $\mathrm{Hf}$ isotopes in zircon during alteration makes $\mathrm{Hf}$ isotopes in single zircon crystals is a powerful tool in constraining the nature of magma sources (Nebel et al., 2007; Griffin et al., 2002; He et al., 2013). In this study, magmatic zircons have $\varepsilon_{\mathrm{Hf}}(\mathrm{t})$ values of +11.83 to +16.87 (Table 5; Fig. 11) and relatively young Hf model 
ages (Table 5), suggesting that the Early Jurassic quartz diorite porphyry was derived from a depleted mantle source with little or no crustal contamination. Similarly, the relatively low $\left({ }^{87} \mathrm{Sr} /{ }^{86} \mathrm{Sr}\right)_{\mathrm{i}}(0.70400$ to 0.70509$)$ and positive $\varepsilon_{\mathrm{Nd}}(\mathrm{t})(5.45$ to 5.94$)$ values with relatively young $\mathrm{Nd}$ model ages also indicate that a dominant contribution from a depleted mantle source (Wu et al., 2007). Moreover, all the samples fall into the orogenic $\mathrm{Pb}$ evolution line and the field between Indian ocean MORB and Indian ocean sediments in the ${ }^{206} \mathrm{~Pb} /{ }^{204} \mathrm{~Pb}$ versus ${ }^{207} \mathrm{~Pb} /{ }^{204} \mathrm{~Pb}$ and ${ }^{206} \mathrm{~Pb} /{ }^{204} \mathrm{~Pb}$ versus ${ }^{208} \mathrm{~Pb} /{ }^{204} \mathrm{~Pb}$ diagrams (Fig. 12), reflecting a mixing of mantle and subducted sediments.
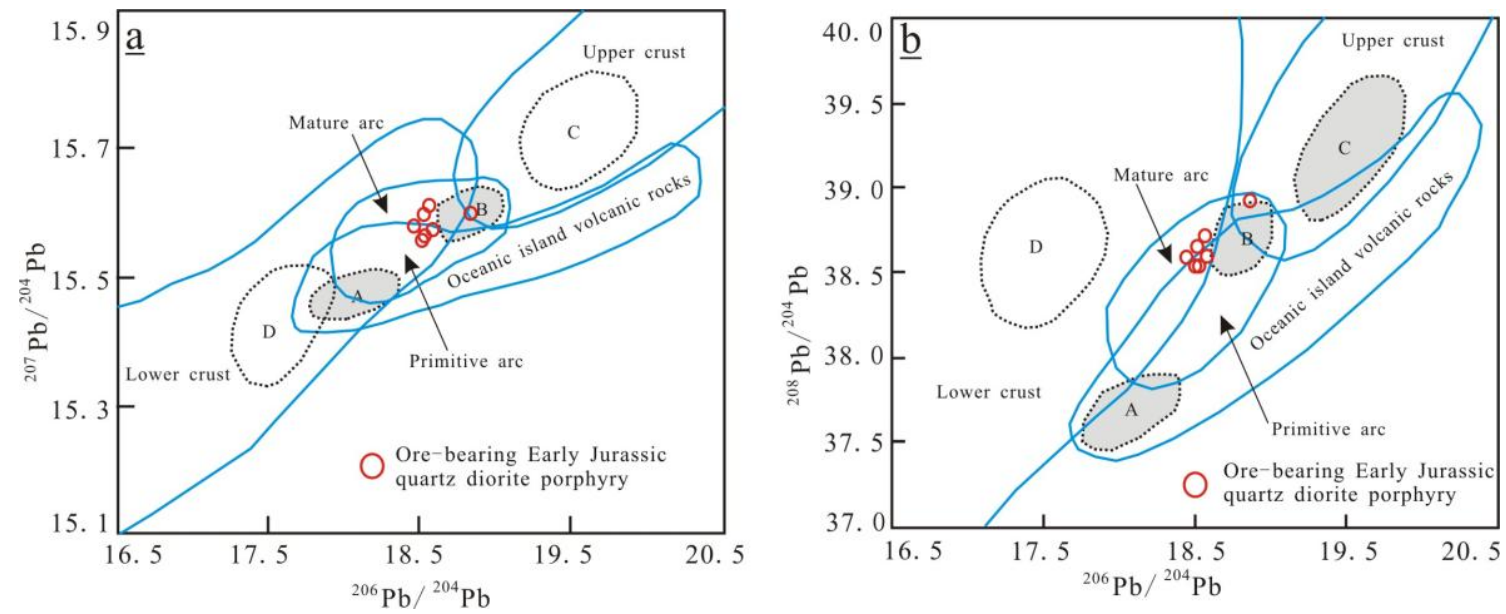

Figure 9. ${ }^{206} \mathrm{~Pb} /{ }^{204} \mathrm{~Pb}$ versus ${ }^{207} \mathrm{~Pb}{ }^{204} \mathrm{~Pb}(a)$ and ${ }^{206} \mathrm{~Pb} /{ }^{204} \mathrm{~Pb}$ versus ${ }^{208} \mathrm{~Pb} /{ }^{204} \mathrm{~Pb}(\mathrm{~b})$ tectonic discrimination diagrams of the Early Jurassic quartz diorite porphyry from the No.2 deposit in the Xiongcun district (after Zartman and Doe, 1981). $A=$ Mantle; $B=$ Orogene; $C=U p p e r$ crust; and D = Lower crust
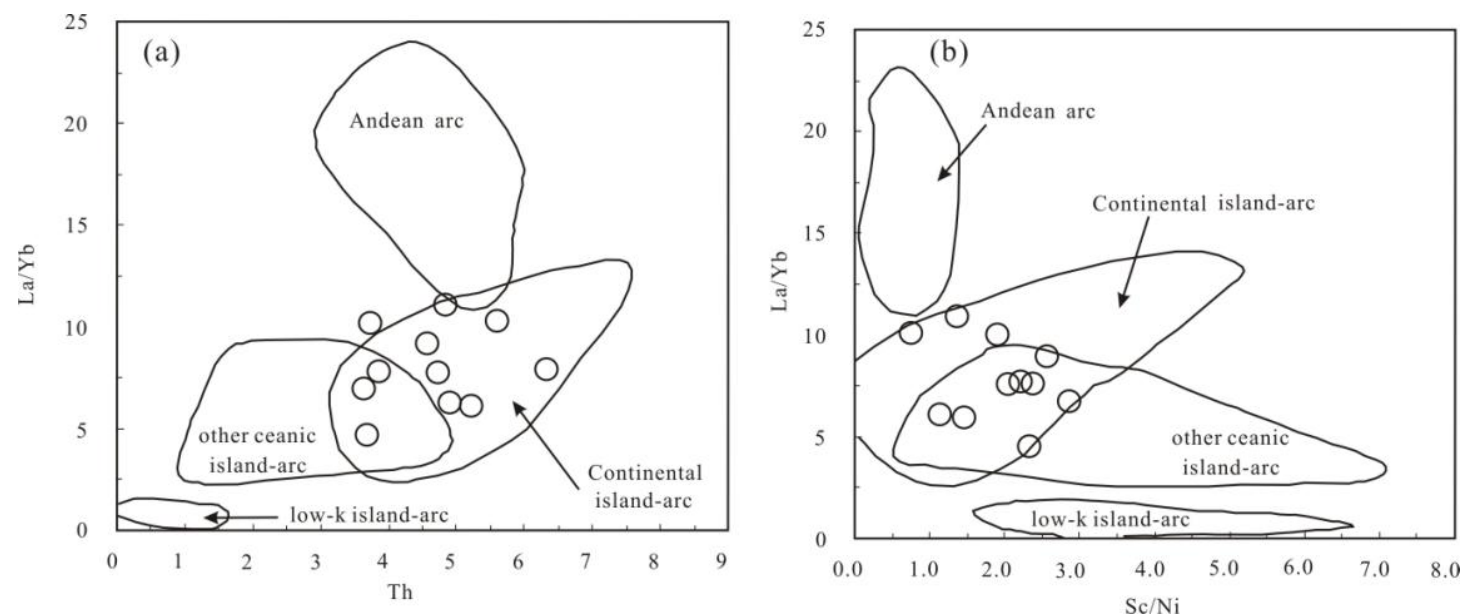

Figure 10. Th versus $L a / Y b(a)$ and $S c / N i$ versus $L a / Y b(b)$ diagrams of the Early Jurassic quartz diorite porphyry from the No.2 deposit in the Xiongcun district (after Bailey, 1981) 


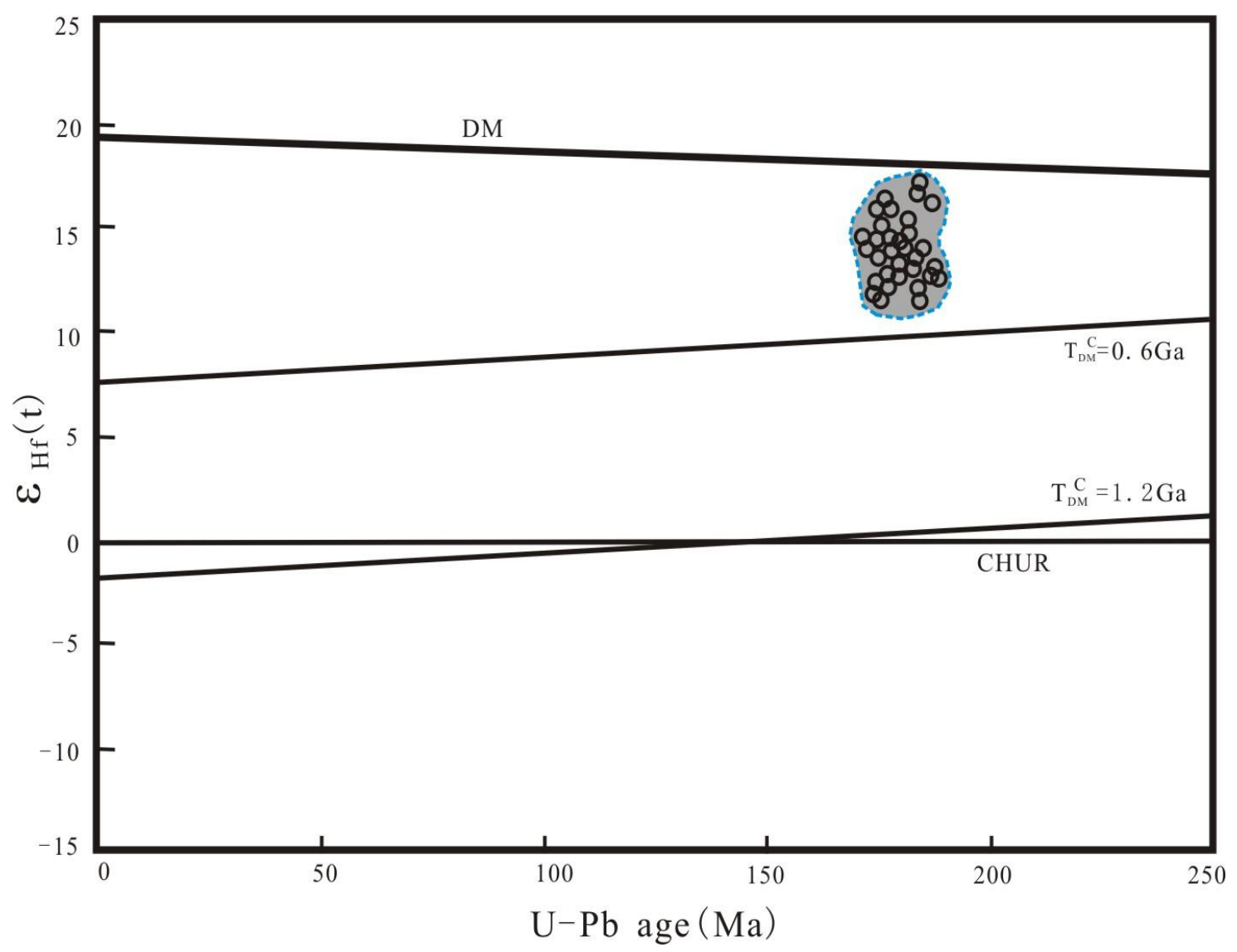

Figure 11. $U$-Pb ages versus $\varepsilon_{H f}(t)$ values of zircons of the Early Jurassic quartz diorite porphyry from the No.2 deposit in the Xiongcun district

The Early Jurassic quartz diorite porphyry has relatively low $(\mathrm{La} / \mathrm{Yb})$ ratios, and high $\mathrm{Yb}$ and $\mathrm{Y}$ values. These characteristics are inconsistent with those of modern adakites (Defant and Drummond, 1990, 1993). Thus involvement of slab melts can be precluded in these rocks. In the $\mathrm{La} / \mathrm{Yb}$ versus $\mathrm{Ba} / \mathrm{La}$ diagram (Fig. 13a), the samples plot into the transitional zone between the Xigaze basalt and sediments, apart from the slab melts and Miocene Gangdese adakitic intrusions, suggesting that the porphyry was derived from a mixture of the depleted mantle and sediments rather than slab melts. In the $\mathrm{Nb} / \mathrm{Y}$ versus Ba diagram (Fig. 13b), all the samples show an influence of fluids related enrichment, implying that subduction-related fluids rather than OIB-related melts were important contributors to the parental magma. Furthermore, the porphyry has high $\mathrm{Th} / \mathrm{Yb}$ ratios ranging from 1.67 to 7.10 (averaging 3.21) (Table 1), suggesting a significant contribution from seduction-related sediments rather than fluid in their origin (Woodhead et al., 2001; Nebel et al., 2007).

A heterogeneous or mixed source composition between two end-members was tested as the possible cause of the $\mathrm{Sr}, \mathrm{Nd}$ and $\mathrm{Pb}$ isotope variations (Fig. 14). The Yarlung Zangbo basalt (Zhang et al., 2005) is used as the inferred depleted mantle component, while the Indian Ocean pelagic sediments (Ben Othman et al., 1989) are taken as the crustal component (Neo-Tethys oceanic sediments). Isotopic modeling indicates that the porphyry could be generated by partial melting of $95 \%$ depleted mantle sourced material mixing with 5\% Neo-Tethyan oceanic sediments (Fig. 14). 

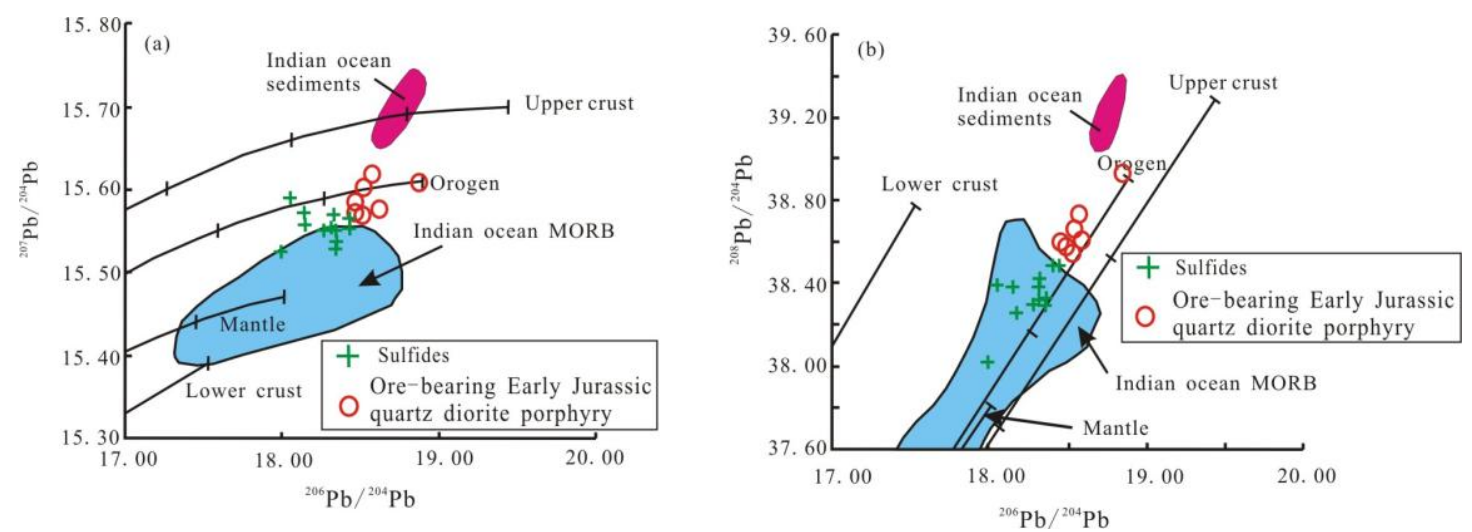

Figure 12. ${ }^{206} \mathrm{~Pb} /{ }^{204} \mathrm{~Pb}$ versus ${ }^{207} \mathrm{~Pb}{ }^{204} \mathrm{~Pb}(a)$ and ${ }^{206} \mathrm{~Pb} / \mathrm{Pb}^{204}$ versus ${ }^{208} \mathrm{~Pb} /{ }^{204} \mathrm{~Pb}(b)$ diagrams of the ore sulfides and Early Jurassic quartz diorite porphyry from the No.2 deposit in the Xiongcun distrit (modified after Zartman and Doe, 1981 and Cheng et al., 2010). Pb isotopic evolution lines of upper crust, lower crust, orogen and mantle are from Zartman and Doe (1981). Indian ocean MORB are from Sun (1980) and Indian ocean sediments from Edwards et al. (1994)
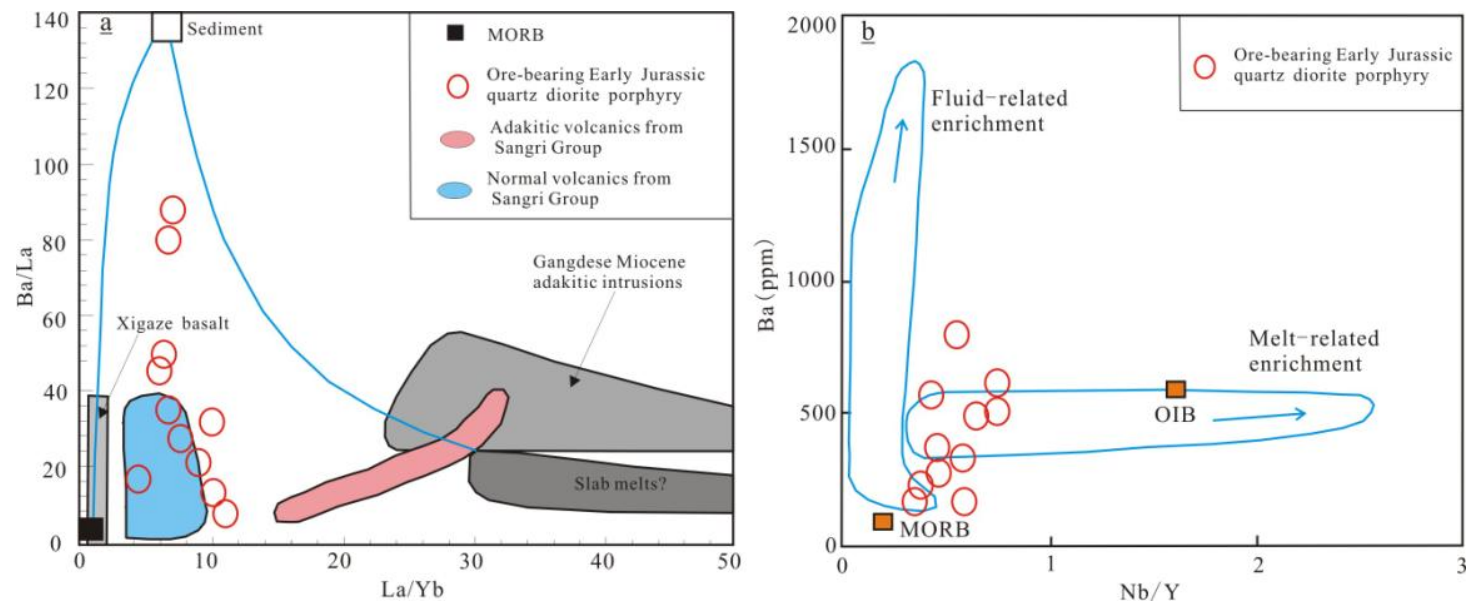

Figure 13. La/Yb versus Ba/La diagram (a; after Zhu et al., 2004) and Ba versus $N b / Y$ diagram (b; after Kepezhinskas et al., 1997) of the Early Jurassic quartz diorite porphyry from the No.2 deposit in the Xiongcun district

In summary, we suggest that the Early Jurassic quartz diorite porphyry of the No.2 deposit in the Xiongcun district was likely generated by partial melting of depleted mantle that was metasomatized by a minor quantity of sediments/fluids $(5 \%)$ released from the subducted Neo-Tethys oceanic slab.

\section{Sources of ore-forming metals}

Lead derived from the upper crust has higher $\mu$ values $(>9.58$; Doe and Zartman, 1979) than lead derived from the mantle $(\mu<8.92$; Zartman and Doe, 1981). The $\mu$ values of ore sulfides from the No.2 deposit in the Xiongcun district vary from 9.34 to 9.49 with an average of 9.40 (Table 2), reflecting a mixing of mantle and crust materials. In the ${ }^{207} \mathrm{~Pb} /{ }^{204} \mathrm{~Pb}$ versus ${ }^{206} \mathrm{~Pb} /{ }^{204} \mathrm{~Pb}$ and ${ }^{208} \mathrm{~Pb} /{ }^{204} \mathrm{~Pb}$ versus ${ }^{206} \mathrm{~Pb} /{ }^{204} \mathrm{~Pb}$ diagrams (Fig. 12), data points of ore sulfides mainly fall within the area between the mantle line and 
orogen line and show the obvious mixing relationship of Indian Ocean MORB and Indian oceanic sediments, which may suggest that the lead was derived mainly from mantle mixed with a small component of crustal materials (subducted sediments). The lead isotope compositions of ore sulfides from the No.2 deposit are similar to those of the porphyry (Fig. 12), suggesting that $\mathrm{Pb}$ both in the Early Jurassic quartz diorite porphyry and ore sulfides may have the same origin.
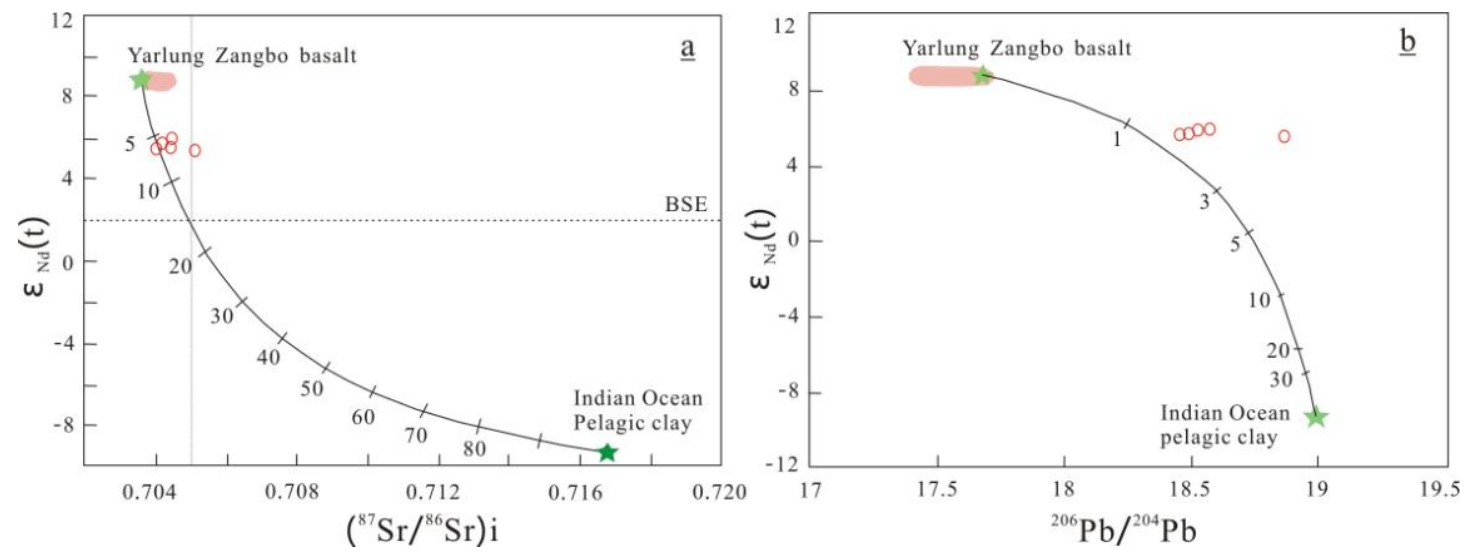

Figure 14. $\left({ }^{87} \mathrm{Sr}{ }^{86} \mathrm{Sr}\right)_{i}$ versus $\varepsilon_{N d}(t)$ diagram (a) and ${ }^{206} \mathrm{~Pb}{ }^{204} \mathrm{~Pb}$ versus $\varepsilon_{N d}(t)$ diagram $(b)$ of the Early Jurassic quartz diorite porphyry from the No.2 deposit in the Xiongcun district (after Zhu et al., 2009). Yarlung Zangbo basalt is from Zhang et al., 2005; Indian Ocean pelagic clay is from Ben Othman et al., (1989)

The $\delta^{34} \mathrm{~S}$ values of ore sulfides from the No.2 deposit range from $-2.4 \%$ to $+1.2 \%$ with an average of $0.06 \%$ and vary around $0.00 \%$ on the histogram of $\delta^{34} \mathrm{~S}$ (Fig. 15). They are similar to those of the mantle-derived sulphur $(0 \pm 3 \%$, Chaussidon and Lorand, 1990). This indicates that the sulfur of the No.2 deposit originated from a mantle source. The $\delta^{34} \mathrm{~S}$ values of ore sulfides from No.2 deposit are similar to those of the porphyry (Fig. 15), probably suggesting that sulfur in the ore sulfides originated from the porphyry.

Mao et al. (1999) and Stein et al. (2001) suggested that deposits derived from mantle sources could have significantly higher Re contents in molybdenites than those deposits that are derived from crustal sources. The Re contents in the molybdenites from the No.2 deposit vary from 1015 to 1354 ppm (Lang et al., 2014a), which is consistent with those in mantle-derived deposits (Re contents in the molybdenites more than hundreds of ppm, Mao et al., 1999). This suggests that the Re in molybdenites of the No.2 deposit could have a mantle source.

\section{Sources of ore-forming fluids}

The $\delta^{18} \mathrm{O}_{\mathrm{H} 2 \mathrm{O}}$ values $(-5.5$ to $+2.9 \%$ o $)$ of the quartz samples from quartz - sulfide veins of the No.2 deposit show a slightly lower oxygen isotopic composition than magmatic water of $\delta^{18} \mathrm{O}_{\mathrm{H} 2 \mathrm{O}}$ values of $5.5-10.0 \%$ o (Taylor, 1974), whereas $\delta^{18} \mathrm{D}_{\mathrm{H} 2 \mathrm{O}}$ values $(-104.0$ to $-57.5 \%$ o) of quartz samples from the quartz - sulfide veins of the No.2 deposit exhibit relatively similar hydrogen isotopic composition to magmatic water of $\delta^{18} \mathrm{D}_{\mathrm{H} 2 \mathrm{O}}$ values of $-50 \%$ to $-85 \%$ (Taylor, 1974 ). In the $\delta^{18} \mathrm{O}_{\mathrm{H} 2 \mathrm{O}}$ versus $\delta^{18} \mathrm{D}_{\mathrm{H} 2 \mathrm{O}}$ diagram (Fig. 16), all the samples plot in the transition area between primary 
magmatic water and geothermal water in Tibet, suggesting that the ore-forming fluids originated from magmatic water that mixed with a small amount of meteoric water during mineralization.

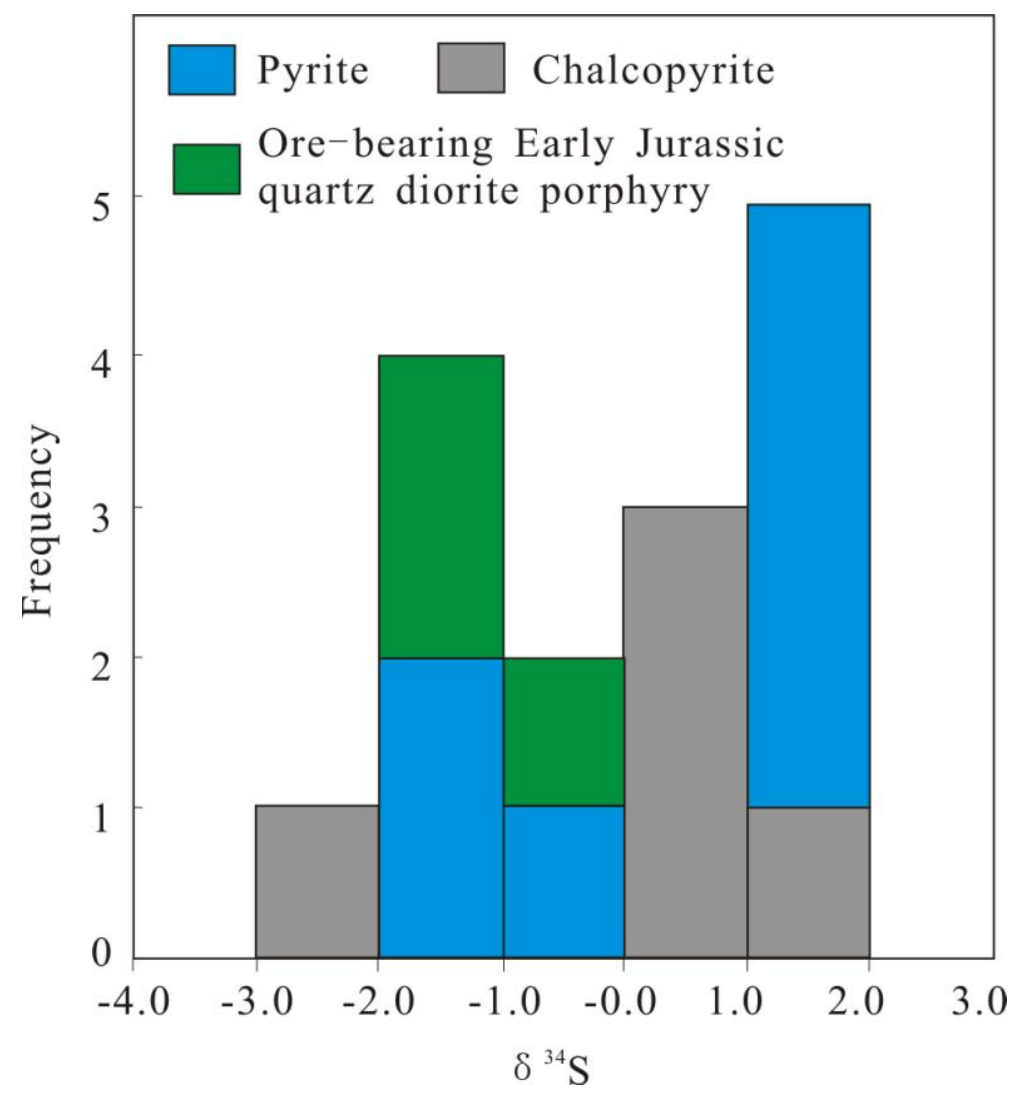

Figure 15. $\delta^{34} S$ histogram for the ore sulfides and Early Jurassic quartz diorite porphyry from the No.2 deposit in the Xiongcun district

\section{Conclusion}

Following conclusions can be drawn from our combined studies on geology and geochemistry for the genesis of the No.2 porphyry copper-gold deposit in the Xiongcun district.

(1) The Xiongcun district is located in the west segment of the GPCB. The No.2 porphyry copper-gold deposit in the Xiongcun district mainly occurs in Early Jurassic quartz diorite porphyry, which caused porphyry-style copper-gold mineralization and associated alterations. The alteration includes potassic alteration, sodic-calcic alteration, chlorite-sericite alteration, phyllic alteration and propylitic alteration. The main hydrothermal veins are quartz - sulfide veins, chlorite - sulfide veins, biotite - sulfide veins and magnetite - sulfide veins. Four main stages of hypogene alteration mineralization and one epigenetic stage developed in the No.2 deposit. 


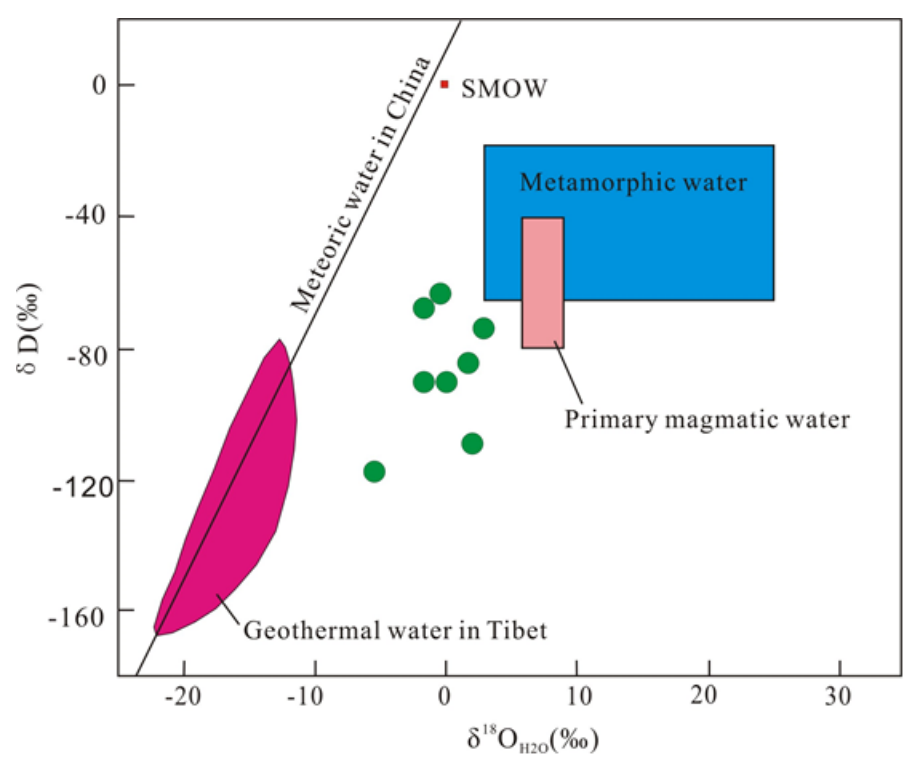

Figure 16. $\delta^{18} O$ versus $\delta D$ of the ore-forming fluids from quartz in the quartz - sulfide vein of the No.2 deposit in the Xiongcun district. The primary magmatic and metamorphic water zones are from Taylor (1974), the meteoric water line is from Zheng et al. (1983), and the geothermal water area is from Zheng et al. (1982)

(2) The Early Jurassic quartz diorite porphyry formed at 181-175 Ma, and the mineralization of the No.2 deposit occurred at $172.6 \pm 2.1 \mathrm{Ma}$. The porphyry has signatures similar to arc rocks, including depletion of $\mathrm{Nb}$, Ta and HFSE and an enrichment of LILE. The uniform and high positive $\varepsilon_{\mathrm{Hf}}(\mathrm{t})$ values, relatively young $\mathrm{Hf}$ model ages for zircons, in combination with the high positive $\varepsilon_{\mathrm{Nd}}(\mathrm{t})$ values and relatively low $(87 \mathrm{Sr} / 86 \mathrm{Sr})_{i}$ ratios of the porphyry, suggest that the No.2 deposit probably formed in an intra-oceanic island arc setting related to the northward intra-oceanic subduction of the Neo-Tethys oceanic slab. The porphyry was likely generated by partial melting of depleted mantle that was metasomatized by a minor quantity of sediments/fluids (5\%) released from the subducted Neo-Tethys oceanic slab.

(3) The $\mathrm{Pb}$ isotopic compositions of ore sulfides indicate that $\mathrm{Pb}$ in the No.2 deposit was mainly derived from the mantle, with a minor input of subducted sediments. The $\delta^{34} \mathrm{~S}$ values of the ore sulfides indicate that sulfur in the No.2 deposit originated from a mantle source. Both the sulfur and lead isotope compositions of the porphyry and sulphide are similar, which indicates that the sulfur and lead of the No.2 deposit were primarily derived from the porphyry magma. The high concentration of $\mathrm{Re}$ in molybdenite indicated that Re in the No.2 deposit is a mantle source. The $\delta^{18} \mathrm{O}_{\mathrm{H} 2 \mathrm{O}}$ and $\delta \mathrm{D}_{\mathrm{H} 2 \mathrm{O}}$ values indicate that the ore-forming fluids of the No.2 deposit were derived from a magmatic water source mixed with minor meteoric water.

Acknowledgments. This research was jointly supported by the National Science Foundation of China (Grant No. 41502079), Sichuan Youth Science and Technology Foundation (2014JQ0047), A Project Supported by Scientific Reserch Fund of Sichuan Provincial Education Department (Grant No. 15ZA0073), State Key Laboratory of Continental Tectonics and Dynamics (Grant No. K201401), State Key Laboratory of Ore Deposit Geochemistry (201503) and China Geological Survey Programs (Grant No. [2012]03-002-055 and [2014]01-028-042). The authors express their appreciation for beneficial helps from Yuan Chen, Zhong Zhang, Reza Tafti, Jianbing Liu, James R. Lang, Mark Rebagliati, and Qi Deng. 


\section{REFERENCES}

[1] Aitchison, J. C., Davis, A. M., Liu, J., Luo, H., Malpas, J. G., McDermid, I. R. C., Wu, H. Y., Ziabrev, S. V., Zhou, M. F. (2000): Remnants of a Cretaceous intra-oceanic subduction system within the Yarlung-Zangbo suture (southern Tibet). - Earth and Planetary Science Letters 183: 231-244.

[2] Bailey, J. C. (1981): Geochemical criteria for a refined tectonic discrimination of orogenic andesites. - Chemical Geology 32: 139-154.

[3] Barrett, T. J., MacLean, W. H. (1994): Chemostratigraphy and hydrothermal alteration in exploration for VHMS deposits in greenstones and younger volcanic rocks. - In: Lentz, D. R. (Ed.) Alteration and Alteration Processes Associated with Ore-Forming Systems. Geological Association of Canada, Short Course Notes 11: 433-467.

[4] Ben, O. D., White, W. M., Patchett, J. (1989): The geochemistry of marine sediments, island arc magma genesis, and crust-mantle recycling. - Earth Planet Science Letter 94: $1-21$.

[5] Bouvier, A., Vervoort, J. D., Patchett, P. J. (2008): The Lu-Hf and Sm-Nd isotopic composition of CHUR: constraints from unequilibrated chondrites and implications for the bulk composition of terrestrial planets. - Earth and Planetary Science Letters 273: 48-57.

[6] Briqueu, L., Bougault, H., Joron, J. L. (1984): Quantification of Nb, Ta, Ti and V anomalies in magmas associated with subduction zones: Petrogenetic implications. - Earth Planet Science Letter: 68: 297-308.

[7] Burnham, C. W. (1979): Magmas and hydrothermal fluids. In: Barnes, H. L. (ed.) Geochemistry of Hydrothermal Ore Deposits (2nd ed.). Wiley, New York: 71-136.

[8] Burnham, C. W., Ohmoto, H. (1980): Late-stage processes in felsic magmatism. - Mining Geoology 8: 1-11.

[9] Chaussidon, M., Lorand, J. P. (1990): Sulphur isotope composition of orogenic spinel lherzolite massifs from Ariege (North-eastern Pyrenees, France): An ion microprobe study. - Geochemical and Cosmochemical Acta 54: 2835-2846.

[10] Cheng, W. B., Gu, X. X., Tang, J. X., Wang, L. Q., Lv, P. R., Zhong, K. H., Liu, X. J., Gao, Y. M. (2010): Lead isotope characteristics of ore sulfides from typical deposits in the Gangdese-Nyainqentanglha metallogenic belt: implications for the zonation of ore-forming elements. - Acta Petrologica Sinica 26: 3350-3362 (in Chinese with English abstract).

[11] Chu, N. C., Taylor, R. N., Chavagnac, V., Nesbitt, R. W., Boella, R. M., Milton, J. A., Germain, C. R., Bayon, G., Burton, K. (2002): Hf isotope ratio analysis using multicollector inductively coupled plasma mass spectrometry: an evaluation of isobaric interference corrections. - Journal of Analytical Atomic Spectrometry 17: 1567-1574.

[12] Chu, M. F., Chung, S. L., Song, B., Liu, D., O'Reilly, S. Y., Pearson, N. J., Ji, J. Wen, D. J. (2006): Zircon U-Pb and Hf isotope constraints on the Mesozoic tectonics and crustal evolution of southern Tibet. - Geology 34: 745-748.

[13] Chu, M. F., Chung, S. L., O'Reilly, S. Y., Pearson, N. J., Wu, F. Y., Li, X. H., Liu, D. Y., Ji, J. Q., Chu, C. H., Lee, H.. Y. (2011): India's hidden inputs to Tibetan orogeny revealed by Hf isotopes of Transhimalayan zircons and host rocks. - Earth and Planetary Science Letters 307: 479-486.

[14] Clayton, R. N., Mayeda, T. K. (1963): The use of bromine and pentafluorine in the extraction of oxygen from oxide and silicates for isotopes analysis. - Geochimica et Cosmochimica Acta 27: 43-52.

[15] Clayton, K. N., O'Neil, J. R., Mayeda, T. K. (1972): Oxygen isotope exchange between quartz and water. - Journal of Geophysical Research 77: 3057-3067. 
[16] Dai, J. G., Wang, C. S., Hébert, R., Li, Y. L., Zhong, H. T., Guillaume, R. (2011). Late Devonian OIB alkaline gabbro in the Yarlung Zangbo Suture Zone: Remnants of the Paleo-Tethys? - Gondwana Research 19: 232-243.

[17] De Bievre, P., Taylor, P. D. P. (1993): Table of the isotopic composition of the elements. International Journal of Mass Spectrometry and Ion Processes 123: 149-166.

[18] Defant, M. J., Drummond, M. S. (1990): Derivation of some modern arc magmas by melting of young subducted lithosphere. - Nature 347: 662-665.

[19] Defant, M. J., Drummond, M. S. (1993): Mount St. Helens: Potential example of the partial melting of the subducted lithosphere in a volcanic arc. - Geology 21: 547-550.

[20] Ding, L., Kapp, P., Wan, X. Q. (2005): Paleocene-Eocene record of ophiolite obduction and initial India-Asia collision, south central Tibet. - Tectonics 24: 1-18.

[21] Doe, B. R., Zartman, R. E. (1979): Plumbotetonics, the phanerozoic. In: Barnes, H.L. (Ed.) Geochemistry of Hydrothermal Ore Deposits. Rinehart and Winston, New York: 22-70.

[22] Durr, S. B. (1996): Provenance of Xigaze fore-arc basin clastic rocks (Cretaceous, south Tibet). - Geological Society of America Bulletin 108: 669-684.

[23] Edwards, C. M. H., Menzies, M. A., Thirlwall, M. F., Morris, J. D., Leeman, W. P., Harmon, R. S. (1994): The transition to potassic volcanism in island arcs: the Ringgit-Beser complex, east Java, Indonesia. - Journal of Petrology 35: 1557-1595.

[24] Griffin, W. L., Wang, X., Jackson, S. E., Pearson, N. J., O'Reilly, S. Y., Xu, X., Zhou, X. (2002): Zircon chemistry and magma mixing, SE China: in-situ analysis of Hf isotopes, Tonglu and Pingtan igneous complexes. - Lithos 61: 237-268.

[25] Guo, L. S., Liu, Y. L, Liu, S. W., Cawood, P. A., Wang, Z. H., Liu, H. F. (2013): Petrogenesis of Early to Middle Jurassic granitoid rocks from the Gangdese belt, Southern Tibet: Implications for early history of the Neo-Tethys. - Lithos 179: 320-333.

[26] Gill, J. B. (1976): Composition and age of Lau Basin and ridge volcanic rocks: implications for evolution of an interarc basin and remnant arc. - Geological Society of America Bulletin 87: 1384-1395.

[27] He, D. F., Zhu, W. G., Zhong, H., Ren, T., Bai, Z. J., Fan, H. P. (2013): Zircon U-Pb geochronology and elemental and Sr-Nd-Hf isotopic geochemistry of the Daocheng granitic pluton from the Yidun Arc, SW China. - Journal of Asian Earth Sciences 67: 1-17.

[28] He, S. D., Kapp, P., DeCelles, P. G., Gehrels, G. E., Heizler, M. (2007): Cretaceous-Tertiary geology of the Gangdese Arc in the Linzhou area, southern Tibet. Tectonophysics 433: 15-37.

[29] Honegger, K., Dietrich, V., Frank, W., Gansser, A., Thöni, M., Trommsdorff, V. (1982): Magmatism and metamorphism in the Ladakh Himalayas (the Indus-Tsangpo suture zone). - Earth and Planetary Science Letters 60: 253-292.

[30] Hou, Z. Q., Qu, X. M., Wang, S. X., Gao, Y. F., Du, A. D., Huang, W. (2003): Re-Os Dating for Molybdenite from Porphyry Copper deposit in Gangdese Metallogenic Belt, Xizang: Ore forming time and dynamics setting. - Science in China 33: 509-618 (in Chinese).

[31] Hou, Z. Q., Gao, Y. F., Qu, X. M., Rui, Z.Y., Mo, X. X. (2004): Origin of adakitic intrusives generated during mid-Miocene east-west extension in southern Tibet. - Earth and Planetary Science Letters 220: 139-155.

[32] Hou, Z. Q., Zhang, H. R., Pan, X. F., Yang, Z. M. (2011): Porphyry Cu (-Mo-Au) deposits related to melting of thickened mafic lower crust: Examples from the eastern Tethyan metallogenic domain. - Ore Geology Reviews 39: 21-45.

[33] Hou, Z. Q., Yang, Z. M., Lu, Y. J., Kemp, A., Zheng, Y. C., Li, Q.Y, Tang, J. X., Yang, Z. S., Duan, L. F. (2015): A genetic linkage between subduction-and collision-related porphyry $\mathrm{Cu}$ deposits in continental collision zones. - Geology 43: 247-250. 
[34] Iizuka, T., Hirata, T. ( 2005) : Improvements of precision and accuracy in in situ Hf isotope microanalysis of zircon using the laser ablation-MC-ICPMS technique. - Chemical Geology 220: 121-137.

[35] Ji, W. Q., Wu, F. Y., Chung, S. L., Li, J. X., Liu, C. Z. (2009): Zircon U-Pb geochronology and Hf isotopic constraints on petrogenesis of the Gangdese batholith, southern Tibet. Chemical Geology 262: 229-245.

[36] Kang, Z. Q., Xu, J. F., Wilde, S. A., Feng, Z. H., Chen, J. L., Wang, B. D., Fu, W. C., Pan, H. B. (2014): Geochronology and geochemistry of the Sangri Group Volcanic Rocks, Southern Lhasa Terrane: implications for the early subduction history of the Neo-Tethys and Gangdese Magmatic Arc. - Lithos 200: 157-168.

[37] Kepezhinskas, P., McDermott, F., Defant, M.. J., Hochstaedter, A., Drummond, M. S., Hawkesworth, C. J., Koloskov, A., Maury, R. C., Bellon, J. (1997): Trace element and $\mathrm{Sr}-\mathrm{Nd}-\mathrm{Pb}$ isotopic constraints on a three-component model of Kamchatka Arc petrogenesis. - Geochimica et Cosmochimica Acta 61: 577-600.

[38] Kuno, H. (1966): Lateral variation of basalt magma types across continental margins and island arcs. - Bulletin of Volcanology 29: 195-222.

[39] Lan, C. Y, Jahn, B. M, Mertzman, S. A, Wu, T. W. (1996): Subduction-related granitic rocks of Taiwan. - Journal of Southeast Asian Earth Sciences 14: 11-28.

[40] Lang, X. H., Tang, J. .X., Li, Z. J., Huang, Y., Ding, F., Yang, H. H., Xie, F. W., Zhang, L., Wang, Q., Zhou, Y. (2014a): U-Pb and Re-Os geochronological evidence for the Jurassic porphyry metallogenic event of the Xiongcun district in the Gangdese porphyry copper belt, southern Tibet, PRC. - Journal of Asian Earth Sciences 79: 608-622.

[41] Lang, X. H., Tang, J. X., Xie, F. W. (2014b): Geological characteristics and exploration potential of the NO. III deposit in the Xiongcun district, Tibet, China. - Advanced Materials Research 868: 217-223.

[42] Lang, X. H., Tang, J. X., Xie, F. W., Li, Z. J., Huang, Y., Ding, F., Yang, H. H., Zhou, Y., Wang, Q. (2014c): Geochronology and geochemistry of the southern porphyry in the Xiongcun district and its geological implications, Tibet. - Geotectonica et Metallogenia 38: 609-620 (in Chinese with English abstract).

[43] Lee, H. Y., Chung, S. L., Lo, C. H., Ji, J., Lee, T. Y., Qian, Q., Zhang, Q. (2009): Eocene Neotethyan slab breakoff in southern Tibet inferred from the Linzizong volcanic record. Tectonophysics 477: 20-35.

[44] Leng, C. B., Zhang, X. C., Hu, R. Z., Wang, S. X., Zhong, H., Wang, W. Q., Bi, X. W. (2012): Zircon U-Pb and molybdenite Re-Os geochronology and Sr-Nd-Pb-Hf isotopic constraints on the genesis of the Xuejiping porphyry copper deposit in Zhongdian, Northwest Yunnan, China. - Journal of Asian Earth Sciences 60: 31-48.

[45] Li, G. M., Rui, Z. Y., Wang, G. M., Lin, F. C., Liu, B., She, H. Q., Feng, C. Y., Qu, W. J. (2005): Molybdenite Re-Os dating of Jiama and Zhibula polymetallic copper deposits in Gangdese metallogenic belt of Tibet and its significance. - Mineral Deposits 24: 481-489 (in Chinese with English abstract).

[46] Li, J. X., Qin, K.. Z., Li, G. M., Xiao, B., Chen, L., Zhao, J. X. (2011): Post-collisional ore-bearing adakitic porphyries from Gangdese porphyry copper belt, southern Tibet: Melting of thickened juvenile arc lower crust. - Lithos 126: 265-277.

[47] Marini, J. C., Chauvel, C., Maury, R. C. (2005): Hf isotope compositions of northern Luzon arc lavas suggest involvement of pelagic sediments in their source. - Contributions to Mineralogy and Petrology 149: 216-232.

[48] Mao, J. W., Zhang, Z. C., Zhang, Z. H., Du, A. D. (1999): Re-Os dating of molybdenites in the Xiaoliugou W-(Mo) deposit in the northern Qilian Mountians and its geological significances. - Geochimica et Cosmochimica Acta 63: 1815-1818. 
[49] Mao, J., Pirajno, F., Lehmann, B., Luo, M. C, Berzina, A. (2014): Distribution of porphyry deposits in the Eurasian continent and their corresponding tectonic settings. - Journal of Asian Earth Sciences 79: 576-584.

[50] Meng, X. J., Hou, Z. Q., Gao, Y. F., Huang, W,. Qu, X. M., Qu., W. J. (2003): Development of porphyry copper-molybdenum-lead-zinc ore-forming system in east Gangdese belt, Tibet: Evidence from Re-Os age of molybdenite in Bangpu copper polymetallic deposit. - Mineral Deposits 22: 246-252 (in Chinese with English abstract).

[51] Miyashiro, A. (1974): Volcanic rock series in island arcs and active continental margins. American Journal of Science 274: 321-355.

[52] Mo, X. X., Zhao, Z. D., Deng J. F., Dong, G. C., Zhou, S., Guo, T. Y., Zhang, S. L., Wang, L. L. (2003): Response of volcanism to the India-Asia collision. - Earth Science Frontiers 10: 135-148 (in Chinese with English abstract).

[53] Mo, X. X., Dong, G. C., Zhao, Z .D., Zhou, S., Wang, L. L., Qiu, R. Z., Zhang, F. Q. (2005): Spatial and temporal distribution and characteristics of granitoids in the Gangdese, Tibet and implication for crustal growth and evolution. - Geological Journal of China Universities 11: 281-290 (in Chinese with English abstract).

[54] McDermid, I., Aitchison, J., Davis, A., Harrison, T., Grove, M. (2002): The Zedong terrane: a Late Jurassic intra-oceanic magmatic arc within the Yarlung-Tsangpo suture zone, southeastern Tibet. - Chemical Geology 187: 267-277.

[55] Nebel, O., Nebel-Jacobsen, Y., Mezger, K., Berndt, J. (2007): Initial Hf isotope compositions in magmatic zircon from early Proterozoic rocks from the Gawler Craton, Australia: a test for zircon model ages. - Chemical Geology 241: 23-37.

[56] Oliver, J. (2006): Geological mapping of the Xietongmen property and continuous areas, Tibet, PRC. - Private Report to Continental Minerals Corporation.

[57] Pan, G. T., Mo, X. .X., Hou, Z. Q., Zhu, D. C., Wang, L. Q., Li, G. M., Zhao, Z. D., Geng, Q. R., Liao, Z. L. (2006): Spatial-temporal framework of the Gangdese orogenic belt and its evolution. - Acta Petrologica Sinica 22: $521-533$ (in Chinese with English abstract).

[58] Pearce, J. A., Harris, N. B. W., Tindle, A. G. (1984): Trace element discrimination diagrams for the tectonic interpretation of granitic rocks. - Journal of Petrology 25: 956-983.

[59] Pearce, J. A., Mei, H. J. (1988): Volcanic rocks of the 1985 Tibet geotraverse: Lhasa to Golmud. - Philosophical Transactions of the Royal Society of London. Series A, Mathematical and Physical Sciences 327: 169-201.

[60] Qi, L., Hu, J., Grégoire, D. C. (2000): Determination of trace elements in granites by inductively coupled plasma mass spectrometry. - Talanta 51: 507-513.

[61] Qu, X. M., Hou, Z. Q., Huang, W. (2001): Is Gangdese porphyry copper belt the second “ Yulong" copper belt? - Mineral Deposits 20: 355-366 (in Chinese with English abstract).

[62] Qu, X. M., Xin, H. B., Xu, W. Y. (2007): Petrogenesis of the ore-hosting volcanic rocks and their contribution to mineralization in Xiongcun superlarge $\mathrm{Cu}-\mathrm{Au}$ deposit, Tibet. Acta Geologica Sinica 81: 964-971 (in Chinese with English abstract).

[63] Ravikant, V., Wu, F. Y., Ji, W. Q. (2009): Zircon U-Pb and Hf isotopic constraints on petrogenesis of the Cretaceous-Tertiary granites in eastern Karakoram and Ladakh, India. Lithos 110: 153-166.

[64] Robinson, B. W., Kusakabe, M. (1975): Quantitative preparation of sulfur dioxide for $32 \mathrm{~S} / 34 \mathrm{~S}$ analyses from sulfides by combustion with cuprous oxide. - Analytical Chemistry 47: 1179-1181.

[65] Rollinson, H. R. (1993): Using geochemical data: Evaluation, presentation, interpretation. - Longman Scientific and Technical Press: 306-308.

[66] Rui, Z. Y., Hou, Z. Q., Qu, X. M., Zhang, L. S., Wang, L. S., Liu, Y. L. (2003): Metallogenetic epoch of Gangdese porphyry copper belt and uplift of Qinghai-Tibet plateau. - Mineral Deposits 22: 217-225 (in Chinese with English abstract). 
[67] Schaltegger, U., Zeilinger, G., Frank, M., Burg, J. P. (2002): Multiple mantle sources during island arc magmatism: U-Pb and $\mathrm{Hf}$ isotopic evidence from the Kohistan arc complex, Pakistan. - Terra Nova 14: 461-468.

[68] Seedorff, E., Dilles, J. J, Proffett J. M. (2005): Porphyry deposits: characteristics and origin of hypogene features. - Economic Geology 29: 251-298.

[69] Shen, P., Shen, Y., Liu, T., Meng, L., Dai, H., Yang, Y. (2009): Geochemical signature of porphyries in the Baogutu porphyry copper belt, western Junggar, NW China. - Gondwana Research 16: 227-242.

[70] Sillitoe, R. H. (2010): Porphyry copper systems. - Economic Geology 105: 3-41.

[71] Simon, K. (2001): Does $\delta$ D from fluid inclusion in quartz reflect the original hydrothermal fluids? - Chemical Geology 177: 483-495.

[72] Stein, H. J., Markey, R. J., Morgan, J. W., Hannah, J. L., Schersten, A. (2001): The remarkable Re-Os chronometer in molybdenite: How and why it works. - Terra Nova 13: 479-486.

[73] Söerlund, U., Patchett, P. J., Vervoort, J. D., Isachsen, C. E. (2004): The Lu-176 decay constant determined by Lu-Hf and U-Pb isotope systematics of Precambrian mafic intrusions. - Earth and Planetary Science Letters 219: 311-324.

[74] Sun, S. S. (1980): Lead isotop stuty of young volcanic rocks from mid-ocean ridges, ocean island and islands arcs. - Philosophical Transactions of the Royal Society Series A. 297: 409-445.

[75] Sun, S. S., McDonough,W. F. (1989): Chemical and isotopic systematics of oceanic basalts: implications for mantle composition and processes. In: Saunders, A.D., Norry, M.J. (Eds.) Magmatism in Ocean Basins. Geological Society Special Publication 42: 313-345.

[76] Taylor, H. P. (1974): The application of oxygen and hydrogen isotope studies to problems of hydrothermal alteration and ore deposition. - Economic Geology 69: 843-883.

[77] Tafti, R., Mortensen, J. K., Lang, J. R., Rebagliati, M., Oliver, J. L. (2009): Jurassic U-Pb and Re-Os ages for the newly discovered Xietongmen $\mathrm{Cu}$-Au porphyry district, Tibet, PRC: Implications for metalogenic epochs in the southern Gangdese belt. - Economic Geology 104: 127-136.

[78] Tafti, R., Lang, J. R., Mortensen, J. K., Oliver, J. L., Rebagliati, C. M. (2014). Geology and Geochronology of the Xietongmen (Xiongcun) Cu-Au Porphyry District, Southern Tibet, China. - Economic Geology 109(7): 1967-2001.

[79] Tang, H. F., Zhao, Z. Q., Han, R. S., Han, Y. J., Su, Y. P. (2008): Primary Hf isotopic study on zircons from the A-type granites in Eastern Junggar of Xinjiang, northwest China. Acta Mineralogica Sinica 28: 335-342 (in Chinese with English abstract).

[80] Tang, J. X., Li, Z. J., Zhang, L., Huang, Y., Deng, Q., Lang, X. H. (2007): Geological characteristics of the Xiongcun type porphyry-epithermal copper-gold deposit. - Acta Mineralogica Sinica (Supp.): 127-128 (in Chinese).

[81] Tang, J. X., Zhang, L., Huang, Y., Wang, C. H., Li, Z. J., Lang, X. H., Wang, Y. (2009a): Period of time for the formation of main geologic bodies in Xiongcun copper-gold deposit, Xietongmen County, Tibet: Evidence from 40Ar/39Ar ages. - Mineral Deposits 28: 759-769 (in Chinese with English abstract).

[82] Tang, J. X., Chen, Y. C., Wang, D. H., Wang, C. H., Xu, Y. P., Qu, W. J., Huang, W., Huang, Y. (2009b): Re-OS dating of molybdenite from the Sharang porphyry molybdenite deposit in Gongbujiangda County, Tibet and its geological significance. - Acta Geologica Sinica 83: 698-704 (in Chinese with English abstract).

[83] Tang, J. X., Li, F. J., Li, Z. J., Zhang, L., Tang, X. Q., Deng, Q., Lang, X. H., Huang, Y., Yao, X. F., Wang, Y. (2010): Period of time for the formation of main geologic bodies in Xiongcun copper-gold deposit, Xietongmen County, Tibet: Evidence from Zircon U-Pb 
ages and Re-Os ages of molybdenite. - Mineral Deposits 29: 461-475 (in Chinese with English abstract).

[84] Tang, J. X., Li, Z. J., Lang, X. H. (2012): Minerals exploration report in the Xiongcun district, Xietongmen County, Tibet. - Private report to Tibet Tianyuan Minerals Exploration LTD. (in Chinese).

[85] Tang J. X., Lang X. H, Xie F. W, Gao, Y. M., Li, Z. J., Huang, Y., Ding, F., Yang, H. H., Zhang, L., Wang, Q., Zhou, Y. (2015): Geological characteristics and genesis of the Jurassic No. I porphyry $\mathrm{Cu}-\mathrm{Au}$ deposit in the Xiongcun district, Gangdese porphyry copper belt, Tibet. - Ore Geology Reviews 70: 438-456.

[86] Todd, E., Gill, J. B., Pearce, J. A. (2012): A variably enriched mantle wedge and contrasting melt types during arc stages following subduction initiation in Fiji and Tonga, southwest Pacific. - Earth and Planetary Science Letters 335: 180-194.

[87] Wang, L. Q., Tang, J. X., Cheng, W. B., Chen, W., Zhang, Z., Lin, X., Luo, M. C., Yao, C. (2015): Origin of the ore-forming fluids and metals of the Bangpu porphyry $\mathrm{Mo}-\mathrm{Cu}$ deposit of Tibet, China: Constraints from $\mathrm{He}-\mathrm{Ar}, \mathrm{H}-\mathrm{O}, \mathrm{S}$ and $\mathrm{Pb}$ isotopes. - Journal of Asian Earth Sciences 103: 276-287.

[88] Winchester, J. A., Floyd, P. A. (1977): Geochemical discrimination of different magma series and their differentiation products using immobile elements. - Chemical Geology 20: 325-343.

[89] Wood, D. A., Joron, J. L., Treuil, M. (1979): A re-appraisal of the use of trace elements to classify and discriminate between magma series erupted in different tectonic setting. Earth and Planetary Science Letters 45: 326-336.

[90] Woodhead, J. D., Hergt, J. M., Davidson, J. P., Eggins, S. M. (2001): Hafnium isotope evidence for conservative element mobility during subduction zone processes. - Earth and Planetary Science Letters 192: 331-346.

[91] Wu, F. Y., Li, X. H., Zheng, Y. F., Gao, S. (2007): Lu-Hf isotopic systematic and their applications in petrology. - Acta petrologica Sinica 23: 185-220 (in Chinese with English abstract).

[92] Xu, W. Y., Qu, X. M., Hou, Z. Q., Yang, D., Yang, Z. S., Pan, F. C., Cui, Y. H., Chen, W. S., Yang, D., Lian, Y. ( 2006): The Xiongcun copper-gold deposit in Tibet: Characteristics, genesis and geodynamic application. - Acta Geologica Sinica 80: 1392-1406 (in Chinese with English abstract).

[93] Xu, W. Y, Pan, F. C., Qu, X. M, Hou, Z. Q, Yang, Z. S, Chen, W. S, Yang, D., Cui, Y. H. (2009): Xiongcun, Tibet: A telescoped system of veinlet-disseminated $\mathrm{Cu}(\mathrm{Au})$ mineralization and late vein-style $\mathrm{Au}(\mathrm{Ag})$-polymetallic mineralization in a continental collision zone. - Ore Geology Reviews 36: 174-193.

[94] Yang, Z. M., Hou, Z. Q., White, N. C., Chang, Z. S., Li, Z. Q., Song, Y. (2009): Geology of the post-collisional porphyry copper-molybdenum deposit at Qulong, Tibet. - Ore Geology Reviews 36: 133-159.

[95] Yin, A., Harrison, M. (2000): Geologic evolution of the Himalayan-Tibetan orogen. Annual Review of Earth and Planetary Sciences 28: 211-280.

[96] Yin, A., Harrison, T. M., Ryerson, F. J., Wenji, C., Kidd, W. S. F., Copeland, P. (1994): Tertiary structural evolution of the Gangese thrust system, southeastern Tibet. - Journal of Geophysical Research 99: 18175-18201.

[97] Zartman, R. E., Doe, B. R. (1981): Plumbotectonics-the model. - Tectonophysics 75: 135-142.

[98] Zhang, G. Y., Zheng, Y. Y., Gong, F. Z., Gao, S. B., Qu, W. J., Pang, Y. C., Shi, Y. R., Yin, S. Y. (2008): Geochronologic constraints on magmatic intrusions and mineralization of the Jiru porphyry copper deposit, Tibet, associated with continent-continent collisional process. - Acta Petrologica Sinica 24: 473-479 (in Chinese with English abstract). 
[99] Zhang, H. F., Xu, W. C., Guo, J. Q., Zong, K. Q., Cai, H. M.,Yuan, H. L. (2007): Zircon $\mathrm{U}-\mathrm{Pb}$ and $\mathrm{Hf}$ isotopic composition of deformed granite in the southern margin of the Gangdese belt, Tibet: Evidence for Early Jurassic subduction of Neo-Tethyan oceanic slab. - Acta Petrologica Sinica 23: 1347-1353 (in Chinese with English abstract).

[100] Zhang, S. Q., Mahoney, J. J., Mo, X. X., Ghazi, A. M., Milani, L., Crawford, A. J., Guo, T. Y., Zhao, Z. D. (2005): Evidence for a widespread Tethyan upper mantle with Indian-Ocean-type isotopic characteristics. - Journal of Petrology 46: 829-858.

[101] Zhao, J. X., Qin, K. Z, Li., G. M., Li, J.X., Xiao, B., Bo, C. L., Yang, Y. C, Li, C., Liu, Y. S. (2014): Collision-related genesis of the Sharang porphyry molybdenum deposit, Tibet: Evidence from zircon $\mathrm{U}-\mathrm{Pb}$ ages, Re-Os ages and $\mathrm{Lu}-\mathrm{Hf}$ isotopes. - Ore Geology Reviews 56: 312-326.

[102] Zheng, Y. Y., Zhang, G. Y., Xu, R. K., Gao, S. B., Pang, Y. C., Cao, L., Du, A. D., Shi, Y. R. (2007): Age limit of ore-forming and rock-forming in Zhuruo porphyry copper deposit, Gangdese, Tibet. - Chinese Science Bulletin 52: 2542-2548 (in Chinese with English abstract).

[103] Zheng, Y. Y, Sun, X., Gao, S. B. (2014): Porphyry Mineralization in the Gangdese Orogenic Belt. - Acta Geologica Sinica (English Edition) 88: 662-664.

[104] Zheng, S. H., Zhang, Z. F., Ni, B. L., Hou, F. G., Shen, M. Z. (1982): Hydrogen and oxygen isotopic studies of thermal waters in Xizang. - Acta Scientiarum Naturalium Universitatis Pekinensis 6: 99-106 (in Chinese with English abstract).

[105] Zheng, S. H., Hou, F. G., Ni, B. L. (1983): Hydrogen and oxygen stable isotopic studies of meteoric waters in China. - Chinese Science Bulletin 13: 801-806 (in Chinese).

[106] Zhu, L. M., Zhang, G. W., Guo, B., Ben, L., Gong, H. J., Wang, F. (2010): Geochemistry of the Jinduicheng Mo-bearing porphyry and deposit, and its implications for the geodynamic setting in East Qinling, PR China. - Chemie der Erde-Geochemistry 70: 159-174.

[107] Zhu, D. C., Zhao, Z. D., Pan, G. T., Lee, Y. H., Kang, Z. Q., Loao, Z. L., Wang, L. Q., Li, G. M., Dong, G. C., Liu, B. (2009): Early cretaceous subduction-related adakite-like rocks of the Gangdese Belt, southern Tibet: Products of slab melting and subsequent melt-peridotite interaction? - Journal of Asian Earth Sciences 34: 298-309.

[108] Zhu, D. C., Zhao, Z. D., Niu, Y., Mo, X. X., Chung, S. L., Hou, Z. Q., Wang, L. Q., Wu, F. Y. (2011): The Lhasa Terrane: Record of a microcontinent and its histories of drift and growth. - Earth and Planetary Science Letters 301: 241-255.

[109] Zhu, D. C., Pan, G. T., Chung, S. L., Liao, Z. L., Wang, L. Q., Li, G. M. (2008): SHRIMP zircon age and geochemical constraints on the origin of Lower Jurassic volcanic rocks from the Yeba Formation, southern Gangdese, south Tibet. - International Geology Review 50: 442-471.

[110] Zhu, D. C., Pan, G. T., Wang, L. Q., Li, G. M., Liao, Z. 1., Geng, Q. R., Liu, B. (2004): Geochemical characteristics and geotectonic significances of volcanic rocks of the Sangri Group, South Gangdese Belt. - The petrology and geodynamics symposium: 425-430 (in Chinese). 